\title{
PENCAPAIAN STANDAR NASIONAL PENDIDIKAN BERDASARKAN HASIL AKREDITASI SMA DI PROVINSI DKI JAKARTA
}

\section{ACHIEVEMENT OF EDUCATIONAL NATIONAL STANDARDS BASED ON ACCREDITATION RESULT OF SENIOR SECONDARY SCHOOL IN JAKARTA}

\author{
Meni Handayani \\ Pusat Penelitian Kebijakan Pendidikan dan Kebudayaan, Balitbang Kemdikbud \\ Gedung E lantai 19, Jl. Jenderal Sudirman - Senayan - Jakarta Pusat \\ e-mail: meni_handayani@yahoo.com
}

Naskah diterima tanggal: 5/11/2015, direvisi akhir tanggal: 18/8/2016, disetujui tanggal: 30/8/2016

\begin{abstract}
Absract: The purpose of this research is to assess the trend in the achievement of eight national standards education and what needs to be improved to increase the achievement. The research used accreditation data from the year of 2011, 2012, and 2013. The achievement tends to increase from 2011 until 2013. The enhancement of accreditation achievement respectively is for the standard of graduate competence, management, content, financing, assessment, facilities and infrastructure. The lowest standard of achievement is the standard of educators and education personnel. There is $13.27 \%$ of schools that do not have library staff. Unfortunately, among those schools that have library staff, $12.32 \%$ of them are below the senior secondary qualifications and do not have a certificate. In addition, $14.69 \%$ of schools do not have a library head and those who have $16.59 \%$ of them do not have proper education or skill background to manage library well. Regarding administrative personnel, only $5.21 \%$ of schools whose administrative personnel have the appropriate educational background. Facilities and infrastructure that is still under the standards are the library space and laboratory space for chemistry and biology. In conclusion, there is an increase in the value of accreditation from 2011 to 2013. Nevertheless, improvement is still needed to meet the eight national education standards.
\end{abstract}

Keywords: National Education Standards, school acreditation, senior secondary school

\begin{abstract}
Abstrak: Tujuan penelitan ini untuk mengkaji perkembangan pencapaian delapan standar nasional pendidikan melalui nilai akreditasi dan apa saja yang perlu diperbaiki dalam meningkatkan pencapaian SNP. Penelitian ini menggunakan data sekunder, yaitu data akreditasi tahun 2011, 2012 dan 2013. Hasil penelitian menunjukkan tahun 2011 terjadi peningkatan nilai akreditasi ke tahun 2012 sampai tahun 2013. Peningkatan pencapaian standar secara berturut-turut terjadi pada standar kompetensi lulusan, standar pengelolaan, standar isi, standar pembiayaan, standar penilaian, dan standar sarana prasarana. Di antara delapan standar yang paling rendah pencapaiannya yakni standar pendidik dan tenaga kependidikan. Penyebabnya adalah sebanyak $13,27 \%$ sekolah tidak memiliki tenaga perpustakaan, walaupun memiliki perpustakaan, 12,32\% kualifikasi pendidikannya di bawah sekolah menengah atas dan tidak memiliki sertifikat. Sekolah tidak memiliki kepala perpustakaan mencapai 14,69\%, dan 16,59\% sekolah yang memiliki kepala perpustakaan kualifikasi pendidikannya diploma dua, itupun bukan berlatar belakang ilmu perpustakaan dan tidak memiliki sertifikat kompetensi pengelolaan perpustakaan. Berkaitan dengan tenaga adminsitrasi, banyak yang tidak memiliki tenaga administrasi. Kalaupun ada, hanya 5,21\% yang memiliki latar belakang pendidikan yang sesuai. Sarana dan prasarana yang perlu dipenuhi yaitu ruang perpustakaan, ruang laboratorium Biologi dan ruang laboratorium
\end{abstract}


Kimia. Hasil Penelitian ini dapat disimpulkan bahwa terjadi peningkatan nilai akreditasi dari tahun 2011 sampai dengan tahun 2013, namun tetap terdapat kekurangan yang harus diperbaiki.

Kata kunci: Standar Nasional Pendidikan, hasil akreditasi, sekolah menengah atas

\section{PENDAHULUAN}

Komitmen Pemerintah, sebagaimana tertulis dalam Undang-Undang Nomor 20 Tahun 2003 tentang Sistem Pendidikan Nasional yaitu melaksanakan pendidikan yang bermutu. Hal itu terdapat dalam Pasal 5 ayat (1): "Setiap warga negara mempunyai hak yang sama untuk memperoleh pendidikan yang bermutu". Hal ini berarti bahwa semua anak Indonesia berhak mendapatkan pendidikan yang bermutu. Dengan adanya Peraturan Pemerintah Nomor 19 Tahun 2005 tentang Standar Nasional Pendidikan (SNP), pengertian bermutu menjadi jelas, yaitu memenuhi standar yang meliputi: 1) standar isi; 2) standar proses; 3) standar kompetensi lulusan; 4) standar pendidik dan tenaga kependidikan; 5) standar sarana dan prasarana; 6) standar pengelolaan; 7) standar pembiayaan; dan 8) standar penilaian. Artinya, jika SNP dilaksanakan maka ada jaminan bahwa mutu pendidikan nasional akan meningkat.

Menurut Tilaar (2006), fungsi SNP yaitu sebagai: 1) pengukuran kualitas pendidikan, 2) pemetaan masalah pendidikan, dan 3) penyusunan strategi dan rencana pengembangan sesudah diperoleh data-data dari evaluasi belajar secara nasional seperti Ujian Nasional.

Pencapaian SNP dapat diukur melalui hasil akreditasi yang dinilai berdasarkan standar. Peningkatan pencapaian SNP dapat dilihat dari hasil akreditasi dari tahun ke tahun. Dalam penelitian ini, hasil akreditasi yang digunakan dari tahun 2011 sampai dengan tahun 2013. Peningkatan atau penurunan nilai akreditasi dari masing-masing SNP perlu dianalisis karena akan menjadi bahan masukan bagi berbagai pemangku kepentingan untuk memastikan proses pembelajaran yang bermutu. Analisis dimaksud harus mampu mengungkapkan kekurangan dari ketercapaian masing-masing standar tersebut.

Penelitian ini fokus pada provinsi DKI Jakarta karena DKI Jakarta sebagai ibukota negara yang pendidikannya menjadi parameter mutu pendidikan di Indonesia dan menjadi acuan daerah lain untuk meningkatkan mutu pendidikannya. Gambaran pencapaian SNP di DKI Jakarta menjadi cerminan mutu pendidikan yang penduduknya bervariasi seperti layaknya Indonesia yang beraneka ragam suku dan bahasanya. Selain itu penelitian ini dapat memberikan gambaran pencapaian SNP dan halhal yang perlu diperbaiki untuk lebih meningkatkan mutu pendidikan di DKI Jakarta.

Berdasarkan paparan di atas, penelitian ini berusaha untuk mencari jawaban atas pertanyaan: Bagaimana kecenderungan pencapaian standar nasional pendidikan berdasarkan hasil akreditasi? dan Apakah yang perlu diperbaiki untuk meningkatkan pencapaian standar tersebut?

Berkaitan pokok permasalahan di atas, tujuan penelitian ini dimaksudkan untuk: 1) mengkaji kecenderungan pencapaian SNP berdasarkan hasil akreditasi di Provinsi DKI Jakarta; dan 2) berbagai hal yang perlu diperbaiki untuk meningkatkan pencapaian Standar Nasional Pendidikan (SNP).

\section{KAJIAN LITERATUR}

\section{Standar Nasional Pendidikan (SNP)}

Pendidikan nasional Indonesia harus sejalan dengan amanat Pasal 31 Undang-Undang Dasar Negara Kesatuan Republik Indonesia Tahun 1945 tentang Pendidikan dan Kebudayaan. Secara operasional pelaksanaan pendidikan merupakan realisasi Undang-Undang Republik Indonesia Nomor 20 Tahun 2003 tentang Sistem Pendidikan 
Nasional. Melalui pendidikan nasional setiap warga negara Indonesia diharapkan menjadi manusia yang bertakwa kepada Tuhan Yang Maha Esa, berakhlak mulia, cerdas, produktif, berdaya saing tinggi, dan bermartabat di tengah pergaulan internasional. Dalam hubungan ini segala upaya perlu dilakukan agar pelaksanaan pendidikan nasional dapat berhasil sehingga tujuan pendidikan nasional dapat tercapai.

Dalam Peraturan Pemerintah (PP) Nomor 19 Tahun 2005, SNP adalah kriteria minimal tentang sistem pendidikan di seluruh wilayah hukum Negara Kesatuan Republik Indonesia. SNP bertujuan menjamin mutu pendidikan nasional dalam rangka mencerdaskan kehidupan bangsa dan membentuk watak serta peradaban bangsa yang bermartabat. Fungsi SNP sebagai dasar dalam perencanaan, terarah dan berkelanjutan sesuai dengan tuntutan perubahan lokal, nasional, dan global. Untuk penjaminan dan pengendalian mutu pendidikan sesuai SNP dilakukan evaluasi, akreditasi dan sertifikasi. Selanjutnya, SNP disempurnakan secara terencana, terarah, dan berkelanjutan sesuai dengan perubahan kehidupan lokal, nasional,dan global.

Lingkup SNP meliputi: a) Standar Isi; b) Standar Proses; c) Standar Kompetensi Lulusan; d) Standar Pendidik dan Tenaga Kependidikan; e) Standar Sarana dan Prasarana; f) Standar Pengelolaan; g) Standar Pembiayaan; dan h) Standar Penilaian Pendidikan. SNP yang digunakan dalam penelitian ini adalah standar yang dikeluarkan oleh PP 19/2005, karena Badan Akreditasi Nasional masih menggunakan acuan PP 19 Tahun 2005 untuk hasil akreditasi tahun 2011, 2012 dan 2013. Masing-masing standar dijabarkan menjadi sebagai berikut.

\section{Standar Isi}

Standar Isi dalam Pasal 5 PP 19/2005 ayat (1) mencakup lingkup materi dan tingkat kompetensi untuk mencapai kompetensi lulusan pada jenjang dan jenis pendidikan tertentu. Standar isi sebagaimana dimaksud pada ayat (1) memuat kerangka dasar dan struktur kurikulum, beban belajar, kurikulum tingkat satuan pendidikan (KTSP), dan kalender pendidikan/akademik.

Standar Isi, selain memuat kerangka dasar dan struktur kurikulum, juga memuat Standar Kompetensi (SK) dan Kompetensi Dasar (KD) setiap mata pelajaran pada setiap semester dari setiap jenis dan jenjang pendidikan dasar dan menengah (BSNP, 2006).

Kurikulum merupakan seperangkat rencana dan pengaturan mengenai tujuan, isi dan bahan pelajaran serta cara yang digunakan sebagai pedoman penyelenggaraan kegiatan pembelajaran untuk mencapai tujuan pendidikan tertentu (BSNP,2006).

Kurikulum sekolah menurut Madus dan Kellaghan (2012) adalah total usaha sekolah untuk mencapai keberhasilan yang diinginkan sekolah dan masyarakat. Kurikulum dalam pengertian ini adalah usaha sekolah untuk mempengaruhi peserta didik, baik di kelas maupun di luar sekolah. Definisi ini disempurnakan lagi menjadi suatu rencana untuk melengkapi seperangkat peluang belajar untuk mencapai tujuan pembelajaran. Kerangka dasar kurikulum adalah rambu-rambu yang ditetapkan untuk dijadikan pedoman dalam penyusunan KTSP dan silabusnya pada setiap satuan pendidikan. KTSP adalah kurikulum operasional yang disusun oleh dan dilaksanakan di masingmasing satuan pendidikan. KTSP terdiri dari tujuan pendidikan tingkat satuan pendidikan, struktur dan muatan kurikulum tingkat satuan pendidikan, kalender pendidikan dan silabus (BSNP, 2006).

\section{Standar Proses}

Dalam PP Nomor 19/2005 pasal 19 ayat (1), Proses pembelajaran pada satuan pendidikan diselenggarakan secara interaktif, inspiratif, menyenangkan, menantang, memotivasi peserta didik untuk berpartisipasi aktif, serta memberikan ruang yang cukup bagi prakarsa, kreativitas, dan kemandirian sesuai dengan bakat, minat, dan perkembangan fisik serta psikologis peserta didik (Sanjaya, 2006). Selain ketentuan sebagaimana dimaksud pada ayat (1), dalam 
proses pembelajaran pendidik memberikan keteladanan dan dalam PP Nomor 19 Tahun 2005 ayat (3), setiap satuan pendidikan melakukan perencanaan proses pembelajaran, pelaksanaan proses pembelajaran, penilaian hasil pembelajaran, dan pengawasan proses pembelajaran untuk terlaksananya proses pembelajaran yang efektif dan efisien.

Untuk mencapai tujuan pendidikan, yakni standar kompetensi yang harus dimiliki siswa, guru sebagai ujung tombak pelaksanaan pendidikan di lapangan sangat menentukan keberhasilannya. Bagaimana pun idealnya suatu kurikulum tanpa diikuti oleh kemampuan guru mengimplementasikannya dalam kegiatan proses pendidikan, maka kurikulum itu tidak memiliki makna. Berkaitan dengan itu, standar proses pendidikan bagi guru berfungsi sebagai pedoman dalam membuat perencanaan program pembelajaran, baik program untuk periode tertentu maupun program pembelajaran harian, dan sebagai pedoman untuk implementasi program dalam kegiatan nyata di lapangan. Standar proses pendidikan sebagai standar pelaksanaan pembelajaran dapat dipengaruhi dan berhubungan dengan ke tujuh standar lainnya (Sanjaya, 2006).

Tahapan dalam proses pembelajaran mulai dari perencanaan dan evaluasi memerlukan guru yang kompeten dalam pelaksanaannya. Proses pembelajaran yang diharapkan adalah dapat menyenangkan dan menantang. Dengan demikian, siswa menjadi merasa selalu ingin belajar tanpa merasa jenuh.

Berkaitan dengan hal itu, UNESCO melalui International Commision on Education for The Twenty First Century, yang antara lain bertujuan untuk mengubah dunia "from technologically divided world where high technology is privillege of the few to technologically united world" mengusulkan empat pilar belajar yaitu "learning, to know, learning to do, learning to be, and learning to live together" (Delors, 1996).

Menerapkan empat pilar tersebut berarti bahwa proses pembelajaran memungkinkan peserta didik dapat menguasai cara memperoleh pengetahuan, berkesempatan menerapkan pengetahuan yang dipelajarinya, berkesempatan untuk berinteraksi secara aktif dengan sesama perserta didik, sehingga dapat menemukan dirinya sendiri. Model pembelajaran seperti ini hanya dapat berlangsung dengan tenaga guru yang mempunyai peralatan memadai, dengan materi yang terpilih dan waktu yang cukup tanpa harus mengejar target untuk ujian nasional, tanpa harus cemas dan takut karena ujian nasional waktunya dimajukan.

Makna mengajar dalam Standar Proses Pendidikan tidak hanya menyampaikan materi pelajaran melainkan juga dimaknai sebagai proses mengatur lingkungan supaya siswa belajar (Sanjaya, 2006). Guru memiliki otonomi penuh dalam mengelola kelas dalam pembelajaran. Metode mengajar yang digunakan guru disesuaikan dengan kondisi siswa dan lingkungan yang dapat menumbuhkan kreativitas siswa. Kinerja guru dalam proses pembelajaran diawasi oleh kepala sekolah dan pengawas sekolah, sehingga untuk mendukung kualitas proses pembelajaran perlu ada peran guru, kepala sekolah, dan pengawas sekolah.

\section{Standar Kompetensi Lulusan}

Standar kompetensi lulusan dalam PP 19/2005 ayat (1) digunakan sebagai pedoman penilaian dalam penentuan kelulusan peserta didik dari satuan pendidikan. Ayat (2) Standar Kompetensi Lulusan sebagaimana dimaksud pada ayat (1) meliputi kompetensi untuk seluruh mata pelajaran atau kelompok mata pelajaran dan mata kuliah atau kelompok mata kuliah. Ayat (3) Kompetensi lulusan untuk mata pelajaran bahasa menekankan pada kemampuan membaca dan menulis yang sesuai dengan jenjang pendidikan. Dalam PP 19/2005/ayat (4), kompetensi lulusan sebagaimana dimaksud pada ayat (1) dan (2) mencakup sikap, pengetahuan, dan keterampilan. Perangkat akreditasi menggunakan PP 19 tahun 2005 sebagai acuan. Peraturan Menteri Pendidikan dan Kebudayaan Nomor 54 tahun 2013 tentang Standar 
Kompetensi Lulusan (SKL) Pendidikan Dasar dan Menengah. Pengertian SKL pada Pemendikbud tersebut cakupannya masih sejalan dengan PP Nomor 19 tahun 2005 yakni SKL adalah kriteria mengenai kualifikasi kemampuan lulusan yang mencakup sikap, pengetahuan dan keterampilan.

\section{Standar Pendidikan dan Tenaga Kependidikan}

Sesuai dengan PP Nomor 19/2005 Pasal 28 ayat (1), pendidik harus memiliki kualifikasi akademik dan kompetensi sebagai agen pembelajaran, sehat jasmani dan rohani, serta memiliki kemampuan untuk mewujudkan tujuan pendidikan nasional. Ayat (2) kualifikasi akademik sebagaimana dimaksud pada ayat (1) adalah tingkat pendidikan minimal yang harus dipenuhi oleh seorang pendidik yang dibuktikan dengan ijazah dan/atau sertifikat keahlian yang relevan sesuai ketentuan perundang-undangan yang berlaku. Pada ayat (3), kompetensi sebagai agen pembelajaran pada jenjang pendidikan dasar dan menengah serta pendidikan anak usia dini meliputi: a) kompetensi pedagogik; b) kompetensi kepribadian; c) kompetensi profesional; dan d) kompetensi sosial. Ayat (4) seseorang yang tidak memiliki ijazah dan/atau sertifikat keahlian sebagaimana dimaksud pada ayat (2) tetapi memiliki keahlian khusus yang diakui dan diperlukan dapat diangkat menjadi pendidik setelah melewati uji kelayakan dan kesetaraan.

Kompetensi menurut Charles E, Johnson, 1974 dalam Sanjaya (2006) adalah sebagai berikut: "Compentency as rational which satisfactirily meets the objective for a desired condition". Menurutnya, kompetensi merupakan perilaku rasional guna mencapai tujuan yang dipersyaratkan sesuai dengan kondisi yang diharapkan. Dengan demikian, suatu kompetensi ditunjukkan oleh penampilan atau unjuk kerja yang dapat dipertanggungjawabkan dalam upaya mencapai suatu tujuan. Berkaitan dengan guru, kompetensi yang dimiliki oleh seorang guru, yaitu meliputi kompetensi pribadi, kompetensi profesional, dan kompetensi sosial kemasyarakatan.

Berdasarkan hasil penelitian menunjukkan bahwa kualifikasi akademik guru yang mengajar di SMK Negeri di Kota Medan masih belum seluruhnya sesuai dengan standar yang telah ditentukan, sedangkan kurikulum dan sarana dan prasarana telah mengacu kepada Peraturan Pemerintah Nomor 19 tahun 2005 tentang Standar Nasional Pendidikan (Harahap, 2009).

\section{Standar Sarana dan Prasarana}

Mengacu pada PP Nomor 19/2005 tentang Standar Nasional Pendidikan, Pasal 42 ayat (1) Setiap satuan pendidikan wajib memiliki sarana yang meliputi perabot, peralatan pendidikan, media pendidikan, buku dan sumber belajar lainnya, bahan habis pakai, serta perlengkapan lain yang diperlukan untuk menunjang proses pembelajaran yang teratur dan berkelanjutan. Ayat (2) setiap satuan pendidikan wajib memiliki prasarana yang meliputi lahan, ruang kelas, ruang pimpinan satuan pendidikan, ruang pendidik, ruang tata usaha, ruang perpustakaan, ruang laboratorium, ruang bengkel kerja, ruang unit produksi, ruang kantin, instalasi daya dan jasa, tempat berolahraga, tempat beribadah, tempat bermain, tempat berkreasi, dan ruang/tempat lain yang diperlukan untuk menunjang proses pembelajaran yang teratur dan berkelanjutan.

Lebih lanjut, Permendiknas RI Nomor 24, Tahun 2007 tentang Standar Sarana dan Prasarana menjelaskan bahwa pelaksanaan pembelajaran dalam pendidikan nasional berpusat pada peserta didik agar dapat: a) belajar untuk beriman dan bertakwa kepada Tuhan Yang Maha Esa, b) belajar untuk memahami dan menghayati, c) belajar untuk mampu melaksanakan dan berbuat secara efektif, d) belajar untuk hidup bersama dan berguna bagi orang lain, dan e) belajar untuk membangun dan menemukan jati diri melalui proses belajar yang aktif, kreatif, efektif, dan menyenangkan. Untuk menjamin terwujudnya hal tersebut diperlukan adanya sarana dan 
prasarana yang memadai. Sarana dan prasarana yang memadai tersebut harus memenuhi ketentuan minimum yang telah ditetapkan dalam standar sarana dan prasarana.

Berdasarkan penelitian Handayani (2014a), baik sekolah yang masuk kategori Sekolah Standar Nasional (SSN) dan sekolah Standar Pelayanan Minimal (SPM) perlu memperbaiki sarana yang berkaitan dengan ketercukupan antara ruang laboratorium dengan jumlah siswa sehingga siswa tidak berdesakan. Artinya ruang laboratorium belum dibuat berdasarkan jumlah siswa yang melakukan praktik dalam ruangan tersebut.

\section{Standar Pengelolaan}

Pengelolaan satuan pendidikan pada jenjang pendidikan dasar dan menengah dalam PP 19/ 2005 Pasal 49 ayat (1), menerapkan manajemen berbasis sekolah yang ditunjukkan dengan kemandirian, kemitraan, partisipasi, keterbukaan, dan akuntabilitas.

Standar pengelolaan pendidikan oleh satuan pendidikan dasar dan menengah dalam Permendiknas terdiri dari: 1) perencanaan program yang meliputi visi, misi, tujuan dan rencana kerja sekolah; 2) Pelaksanaan rencana kerja yang meliputi pedoman yang mengatur berbagai aspek pengelolaan secara tertulis, struktur organisasi, pelaksanaan kegiatan sekolah, bidang kesiswaan (sekolah menyusun dan menetapkan petunjuk pelaksanaan operasional mengenai proses penerimaan peserta didik, bidang kurikulum dan kegiatan pembelajaran, bidang pendidik dan tenaga kependidikan (sekolah menyusun program pendayagunaan pendidik dan tenaga kependidikan), bidang sarana dan prasarana (sekolah menetapkan kebijakan program secara tertulis mengenai pengelolaan sarana dan prasarana, bidang keuangan dan pembiayaan (sekolah menyusun pedoman pengelolaan biaya investasi dan operasional yang mengacu pada standar pembiayaan), budaya dan lingkungan sekolah (sekolah menciptakan suasana, iklim, dan lingkungan pendidikan yang kondusif untuk pembelajaran yang efisien dalam prosedur pelaksanaan) dan peran serta masyarakat dan kemitraan sekolah (sekolah melibatkan warga dan masyarakat pendukung sekolah dalam mengelola pendidikan); 3) Pengawasan dan evaluasi yang meliputi program pengawasan (sekolah menyusun program pengawasan secara obyektif, bertanggung jawab dan berkelanjutan), evaluasi diri (sekolah melakukan evaluasi diri terhadap kinerja sekolah, evaluasi dan pengembangan KTSP, evaluasi pendayagunaan pendidik dan tenaga kependidikan yang direncanakan secara komprehensif pada setiap akhir semester dengan mengacu pada standar pendidik dan tenaga kependidikan, akreditasi sekolah (sekolah menyiapkan bahanbahan yang diperlukan untuk mengikuti akreditasi sesuai dengan peraturan perundangundangan yang berlaku); 4) Kepemimpinan sekolah; 5) Sistem Informasi Manajemen; 6) Penilaian khusus, keberadaan sekolah yang pengelolaannya tidak mengacu kepada Standar Nasional Pendidikan dapat memperoleh pengakuan Pemerintah atas dasar rekomendasi BSNP.

Pada pertengahan dekade 1950-an, dua orang guru besar dari Universitas California Los Angeles, merumuskan fungsi-fungsi manajemen urut-urutan sebagai berikut: perencanaan (planning), pengorganisasian (organizing), pengisian jabatan (staffing), pengarahan (directing), dan pengawasan (controlling). Rumusan fungsi-fungsi manajemen seperti rumusan Konontz \& O'Donnel seperti disebutkan di atas dengan berbagai variasi. Ghiselli (1970) menyampaikan empat fungsi manajemen dalam buku Lussier meliputi: 1) Planning, 2) Organizing, 3) Leading dan 4) controlling. Unsur-unsur pengelolaan yang diangkat dalam Standar Nasional Pendidikan terutama adalah perencanaan, pelaksanaan organizing, kepemimpinan dan pengawasan.

\section{Standar Pembiayaan}

Pembiayaan pendidikan dalam PP 19/2005 pasal 62 ayat (1) terdiri atas biaya investasi, biaya operasi, dan biaya personal. Dalam ayat (2) 
Biaya investasi satuan pendidikan sebagaimana dimaksud pada ayat (1) meliputi biaya penyediaan sarana dan prasarana, pengembangan sumber daya manusia, dan modal kerja tetap. Ayat (3) Biaya personal sebagaimana dimaksud pada ayat (1) meliputi biaya pendidikan yang harus dikeluarkan oleh peserta didik untuk bisa mengikuti proses pembelajaran secara teratur dan berkelanjutan dan ayat (4) Biaya operasi satuan pendidikan sebagaimana dimaksud pada ayat (1) meliputi: (i) gaji pendidik dan tenaga kependidikan serta segala tunjangan yang melekat pada gaji, (ii) bahan atau peralatan pendidikan habis pakai, dan (iii) biaya operasi pendidikan tak langsung berupa daya, air, jasa telekomunikasi, pemeli haraan sarana dan prasarana, uang lembur, transportasi, konsumsi, pajak, asuransi, dan lain sebagainya.

Lebih lanjut, Permendiknas RI Nomor 69/ 2009 yang mengamanatkan bahwa Standar Biaya Operasional Nonpersonalia (SBON) adalah "bagian" dari biaya keseluruhan dana pendidikan biaya operasional yang diperlukan untuk membiaya kegiatan operasional sekolah nonpersonalia selama satu tahun agar kegiatan pendidikan berjalan secara teratur dan berkelanjutan sesuai SNP. Menurut Fattah (2008), terdapat korelasi antara besarnya biaya pendidikan terhadap peningkatan mutu pendidikan dasar. Oleh karena itu, perencana pendidikan harus menggunakan sebaik mungkin sumber daya yang tersedia dan mengawasinya.

Agar kualitas pendidikan tingkat SMA meningkat, maka Depdiknas memberikan standar biaya pengeluaran nonpersonalia untuk kegiatan pendidikan, dengan besaran sebagai berikut: per peserta didik (SMA: bahasa Rp.960.000,-, IPS Rp.960.000,-, IPA Rp.1.010.000,-), per kelas dengan jumlah peserta didik maksimal (SMA: bahasa Rp.30.720.000,-, IPS Rp.30.720.000,-, IPA Rp.32.320.000,-), per sekolah (SMA: bahasa Rp.184.320.000,-, IPS Rp.184.320.000,-, IPA Rp.193.920.000,-), biaya pengelolaan Alat Tulis Sekolah serta biaya pengelolaan Bahan dan Alat Habis Pakai (BAHP), masing masing besarnya minimum $10 \%$ dari biaya total "SBON". Untuk SMA, ketentuan jumlah rombongan belajar per sekolah/program keahlian dan jumlah peserta didik per rombongan belajar untuk perhitungan biaya operasi nonpersonalia adalah enam rombongan belajar dengan setiap rombongan belajar berisi 32 peserta didik (Permendiknas RI Nomor 69/2009).

\section{Standar Penilaian}

Penilaian pendidikan pada jenjang pendidikan dasar dan menengah dalam PP 19/2005 pasal 63 ayat (1) terdiri atas: a) penilaian hasil belajar oleh pendidik; b) penilaian hasil belajar oleh satuan pendidikan; dan c) penilaian hasil belajar oleh Pemerintah.

Penilaian Hasil Belajar oleh Pemerintah dalam PP 19/2005 Pasal 66 ayat (1) disebutkan bahwa penilaian hasil belajar sebagaimana dimaksud dalam Pasal 63 ayat (1) huruf c bertujuan untuk menilai pencapaian kompetensi lulusan secara nasional pada mata pelajaran tertentu dalam kelompok mata pelajaran ilmu pengetahuan teknologi dan dilakukan dalam bentuk ujian nasional. Dalam ayat (2) tertulis Ujian nasional dilakukan secara obyektif, berkeadilan, dan akuntabel. Sedangkan dalam ayat (3) Ujian nasional diadakan sekurang-kurangnya satu kali dan sebanyak-banyaknya dua kali dalam satu tahun pelajaran.

\section{Akreditasi Sekolah}

Badan Akreditasi Nasional Sekolah/Madrasah yang selanjutnya disebut BAN-S/M dalam pasal 1 butir 2 adalah badan evaluasi mandiri yang menetapkan kelayakan program dan/atau satuan pendidikan jenjang pendidikan dasar dan menengah jalur formal dengan mengacu pada SNP Permendikbud Nomor 59/2012. Untuk penjaminan dan pengendalian mutu pendidikan sesuai dengan Standar Nasional Pendidikan dilakukan evaluasi, akreditasi, dan sertifikasi. Hasil akreditasi dapat dijadikan sebagai salah satu alat ukur ketercapaian standar nasional pendidikan.

Akreditasi sekolah merupakan kegiatan penilaian yang dilakukan oleh pemerintah dan/ 
atau lembaga mandiri yang berwenang untuk menentukan kelayakan program dan/atau satuan pendidikan pada jalur pendidikan formal dan nonformal pada setiap jenjang dan jenis pendidikan, berdasarkan kriteria yang telah ditetapkan,sebagai bentuk akuntabilitas publik yang dilakukan secara obyektif, adil, transparan dan komprehensif dengan menggunakan instrumen dan kriteria yang mengacu kepada Standar Nasional Pendidikan (Kemdiknas, 2011).

Latar belakang adanya kebijakan akreditasi sekolah di Indonesia adalah bahwa setiap warga negara berhak memperoleh pendidikan yang bermutu. Untuk dapat menyelenggarakan pendidikan yang bermutu, maka setiap satuan/ program pendidikan harus memenuhi atau melampaui standar yang dilakukan melalui kegiatan akreditasi terhadap kelayakan setiap satuan/program pendidikan.

Undang-Undang Nomor 20 tahun 2003 tentang Sistem Pendidikan Nasional Bab XVI Bagian Kedua Pasal 60 tentang Akreditasi, berbunyi sebagai berikut: 1) Akreditasi dilakukan untuk menentukan kelayakan program dan satuan pendidikan pada jalur pendidikan formal dan nonformal pada setiap jenjang dan jenis pendidikan; 2) Akreditasi terhadap program dan satuan pendidikan dilakukan oleh lembaga mandiri yang berwenang sebagai bentuk akuntabilitas publik; dan 3) Akreditasi di lakukan atas dasar kriteria yang bersifat terbuka.

Sejalan dengan hal di atas, dalam Peraturan Pemerintah Nomor 19 tahun 2005 tentang Standar Nasional Pendidikan, Pasal 86 dinyatakan hal-hal sebagai berikut: 1) Pemerintah melakukan akreditasi pada setiap jenjang dan satuan pendidikan untuk menentukan kelayakan program dan/satuan pendidikan; 2) Kewenangan akreditasi sebagaimana di maksud pada ayat (1) dapat pula dilakukan oleh lembaga mandiri yang di beri kewenangan oleh Pemerintah untuk melakukan akreditasi; 3) Akreditasi sebagaimana di maksud pada ayat (1) dan ayat (2) sebagai bentuk akuntabilitas publik dilakukan secara obyektif, adil, transparan, dan komprehensif dengan menggunakan instrumen dan kriteria yang mengacu kepada Standar Nasional Pendidikan.

Untuk melaksanakan mandat perundangan tersebut, Menteri Pendidikan dan Kebudayaan selanjutnya menerbitkan Permendikbud Nomor 59 tahun 2012 tentang Badan Akreditasi Nasional. Pada Pasal 1 ayat (2) Permendikbud Nomor 59 tahun 2012 dinyatakan bahwa Badan Akreditasi Nasional Sekolah/Madrasah yang selanjutnya disebut BAN-S/M adalah badan evaluasi mandiri yang menetapkan kelayakan program dan satuan pendidikan jenjang pendidikan dasar dan menengah jalur formal dengan mengacu pada Standar Nasional Pendidikan.

Sekolah yang akan diakreditasi, sebelum menghadapi evaluasi yang dilakukan oleh Badan Akreditasi Sekolah maka melalui Evaluasi Diri Sekolah (EDS). Menurut Hendarman (2014) EDS yang dilakukan di Indonesia merupakan wujud komitmen untuk menjamin bahwa setiap satuan pendidikan pada jalur formal melakukan penjaminan mutu pendidikan bertujuan untuk memenuhi atau melampaui Standar Nasional Pendidikan yang dilakukan secara bertahap, sistematis dan terencana.

Sistem pengembangan dan peningkatan mutu pendidikan harus dibangun dan dikembangkan secara nasional dalam upaya meningkatkan daya saing, citra dan akuntabilitas publik. Akreditasi merupakan rangkaian proses dan sistem mengumpulkan, menganalisis dan melaporkan data mengenai kinerja satuan pendidikan (Sri Haryati, 2012).

\section{METODE}

Pendekatan penelitian ini menggunakan pendekatan kuantitatif. Data yang digunakan adalah data sekunder dari Badan Akreditasi Provinsi dan Badan Akreditasi Nasional. Hasil akreditasi SMA per standar untuk Provinsi DKI Jakarta. Aspek yang dinilai dalam akreditasi terdiri dari nilai Standar Isi, Standar Proses, Standar Kompetensi Lulusan, Standar Pendidik dan Tenaga Kependidikan, Standar Pengelolaan, Standar Pembiayaan, dan Standar Penilaian. 
Data yang dianalisis adalah data tahun 2011, 2012 dan 2013. Pada tahun 2011 jumlah sekolah di Provinsi DKI Jakarta yang terakreditasi sebanyak 98 SMA, pada tahun 2012 jumlah sekolah yang terakreditasi sebanyak 44 SMA, sedangkan pada tahun 2013 jumlah sekolah yang terakreditasi sebanyak 69 SMA. Jumlah keseluruhan sekolah yang dianalisis 211 SMA.

Setelah dokumen hasil akreditasi terkumpul, kemudian dipilah menurut standar isi, standar proses, standar kompetensi lulusan, standar pendidik dan tenaga kependidikan, standar pengelolaan, standar sarana prasarana, standar pembiayaan dan standar penilaiaan dari tahun 2011, 2012 dan 2013. Nilai akreditasi per standar dianalisis untuk mendapat distribusi frekuensi yang antara lain terdiri dari standar deviasi dan rata-rata skor setiap standar. Hasil rata-rata skor setiap standar dibandingkan dari tahun 2011, 2012 dan 2013 untuk melihat kecenderungan peningkatan atau penurunan.

\section{HASIL DAN PEMBAHASAN}

Status akreditasi masing-masing sekolah bervariasi mulai dari akreditasi $A, B$ maupun $C$. Hasil akreditasi yang dianalisis adalah skor nilai masing-masing standar yang bervariasi sesuai dengan besarnya skor masing-masing sekolah. Analisis data dari hasil akreditasi setiap standar dijabarkan sebagai berikut.

\section{Standar Isi}

Penilaian akreditasi berdasarkan 8 SNP mulai diluncurkan pada tahun 2005/2006. Standar isi yang meliputi KTSP juga mulai dijalankan. Pada Grafik 1 terlihat bahwa rata-rata pencapaian standar isi pada tahun 2011 pada angka 87,84 meningkat sebesar 4,24 pada tahun 2012 dan terus meningkat pada tahun 2013 sebesar 0,65. Semakin meningkatnya pencapaian standar isi karena sudah lama berjalannya Kurikulum Tingkat Satuan Pendidikan. Aspek yang masih kurang dalam pencapaian standar isi adalah kesesuaian antara Standar Kompetensi, Kompetensi Dasar dan indikator-indikatornya di semua mata pelajaran $(3,32)$ kurang sesuai. Selain itu, dari butir yang ditanyakan, yang kurang adalah keterlibatan berbagai pihak dalam penyusunan silabus mata pelajaran muatan lokal $(7,1 \%)$. Walaupun sekolah-sekolah banyak yang telah melaksanakan kurikulum 2013, masukan dari analisis butir standar isi dengan perangkat akreditasi lama masih bermanfaat untuk memperbaiki mutu pembelajaran di sekolah.

Berdasarkan penelitian Panjaitan (2013) tentang Analisis Standar Isi Bahasa Inggris ditemukan bahwa keterbacaan SK dan KD rendah sehingga guru salah membaca SK dan KD. Selain itu dapat dikatakan bahwa rumusan kompetensi yang tidak jelas, terlalu umum dan terlalu teoretis akan menimbulkan kesulitan bagi guru dalam membuat perencanaan proses

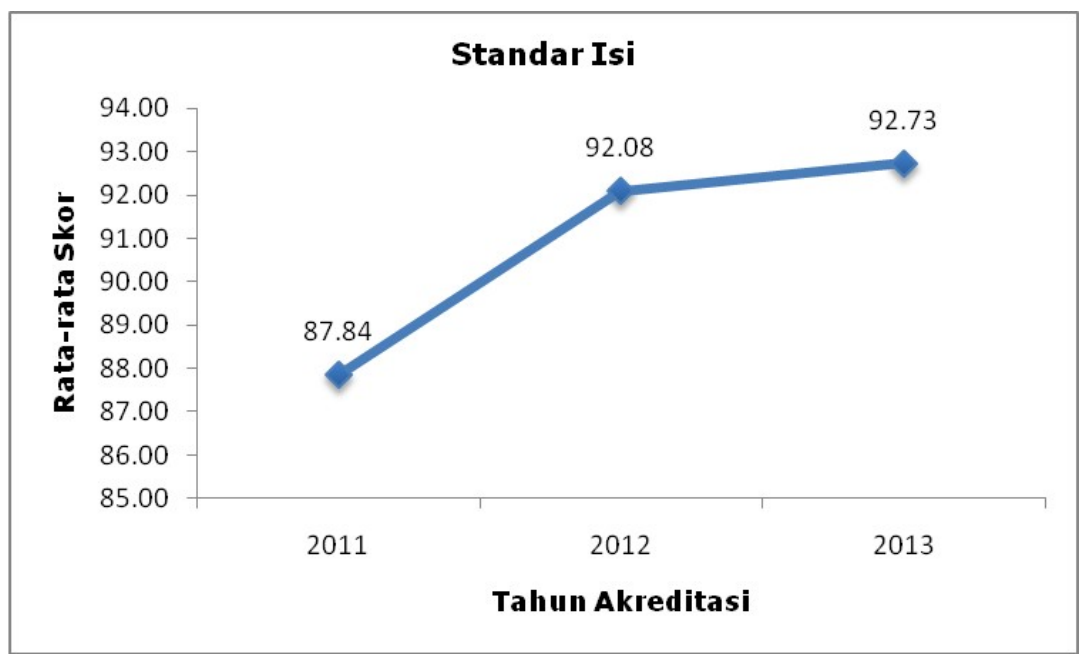

Grafik 1 Kecenderungan Rata-rata Skor Nilai Standar Isi Hasil Akreditasi 
pembelajaran berupa silabus maupun RPP serta mengimplementasikannya. Hal ini semakin mempersulit guru menjawab tantangan desentralisasi untuk mengembangkan kurikulum tingkat satuan pendidikan hanya berdasarkan SKL dan SI, yang hanya berisi rumusan-rumusan SK dan KD yang harus dikuasai peserta didik. Apabila diimplementasikan akan berdampak pada kualitas pembelajaran yang justru tidak difokuskan pada pengembangan keterampilan berbahasa Inggris untuk melakukan berbagai kegiatan yang berguna bagi hidup anak saat ini dan yang akan datang.

Rendahnya keterbacaan SK dan KD oleh guru menjadi salah satu penyebab kurang sesuainya antara Standar Kompetensi, Kompetensi Dasar dan indikator-indikatornya di semua mata pelajaran. Namun, kurikulum 2006 sudah berjalan cukup lama sehingga kendala tersebut lama kelamaan dapat teratasi melalui pembelajaran. Untuk selanjutnya Standar Kompetensi dan Kompetensi Dasar dapat dibuat lebih operasional dan mudah dipahami oleh guru.

Tahun 2013, mulai digunakan kurikulum 2013. istilah Standar Kompetensi diganti dengan Kompetensi Inti. Aspek sikap menjadi perhatian dalam kurikulum 2013 selain aspek pengetahuan dan keterampilan. Kompetensi Inti dibagi menjadi empat yakni kompetensi Inti spiritual, kompetensi inti sosial, kompetensi inti pengetahuan dan kompetensi inti keterampilan.
Kompetensi Dasar di setiap mata pelajaran mengalami beberapa perubahan. Silabus yang pada saat KTSP disusun oleh sekolah, maka di kurikulum 2013, silabus disusun oleh pemerintah. Perbedaan ini tentunya membutuhkan penyesuaian terhadap perangkat penilaian akreditasi. Kesesuaian antara kompetensi dasar dan indikator-indikator di semua mata pelajaran juga merupakan hal yang perlu diperhatikan dalam kurikulum 2013.

Mata pelajaran muatan lokal di daerah, biasanya berupa bahasa daerah. Terdapat beberapa daerah yang mengisi muatan lokal dengan pengenalan daerahnya dan pelajaran budi pekerti. Silabus mata pelajaran muatan lokal disusun oleh guru, kepala sekolah, komite sekolah, dinas pendidikan dan instansi terkait karena muatan lokal berisi tentang kekhasan di suatu daerah.

\section{Standar Proses}

Hasil akreditasi untuk standar proses pada tahun 2011 mencapai skor rata-rata 85,36, terus meningkat sebesar 4,24 pada tahun 2012 dan terus meningkat 0,65 pada tahun 2013, hal ini dapat dilihat pada Grafik 2. Walaupun terjadi peningkatan pencapaian standar proses setiap tahunnya, namun masih ada kekurangan yang ditemukan yakni, evaluasi proses pembelajaran yang dilakukan oleh 4,27\% kepala sekolah hanya pada satu aspek, bahkan tidak melakukan

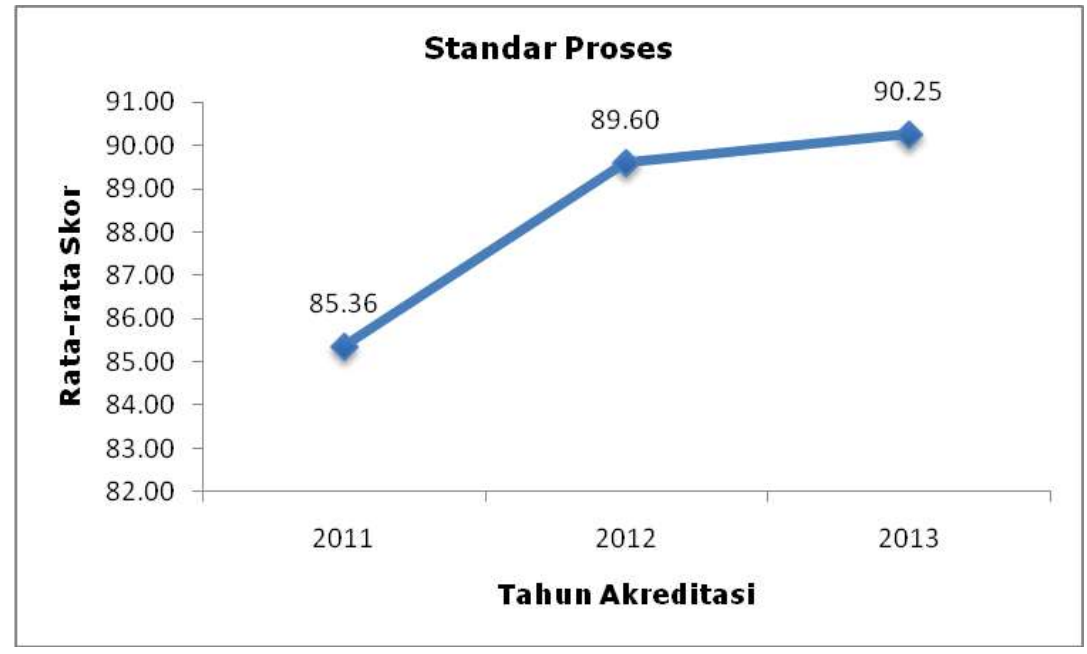

Grafik 2 Kecenderungan Rata-rata skor nilai Standar Proses Hasil Akreditasi 
evaluasi. Biasanya aspek yang paling diperhatikan adalah aspek pelaksanaan proses pembelajaran. Evaluasi seharusnya dilakukan oleh kepala sekolah mulai dari perencanan pembelajaran yang antara lain berisi tentang materi yang diajarkan, metode mengajar, dan cara menilai. Kemudian dalam proses pembelajaran dievaluasi oleh kepala sekolah apakah sesuai dengan perencanaan. Setelah proses pembelajaran dilakukan penilaian terhadap hasil belajar siswa yang disesuaikan dengan perencanaan pembelajaran.

Kepala sekolah memiliki kendala dalam melakukan evaluasi karena jumlah guru yang dievaluasi terlalu banyak. Perlu strategi dari kepala sekolah dalam melakukan evaluasi agar dapat menjangkau semua guru. Salah satu cara yang biasa digunakan kepala sekolah adalah meminta bantuan guru senior untuk melakukan evaluasi terhadap guru muda sesuai dengan mata pelajaran yang diajarkan oleh guru senior. Hasil evaluasi guru senior dilaporkan dan ditindaklanjuti oleh kepala sekolah.

Selain itu, hal yang kurang adalah mengembangkan silabus secara mandiri atau cara lainnya berdasarkan standar isi, standar kompetensi lulusan, dan panduan penyusunan KTSP $(6,2 \%)$. Bagi sekolah-sekolah yang menjalankan KTSP 2006, masih ada sekolah yang belum mengembangkannya secara mandiri. Sekolah yang belum mengembangkan silabus secara mandiri cenderung mengikuti silabus sekolah lain yang karakteristiknya sama.

Upaya peningkatan mutu pendidikan melalui peningkatan proses pembelajaran terkait dengan peran guru pebelajar, guru sebagai pembimbing, guru sebagai fasilitator dan guru sebagai pengelola administrasi sekolah (Dominggus \& Papilaya, 2014). Peran kepala sekolah dan pengawas sebagai pengendali mutu untuk mengawasi dan mengevaluasi hasil kinerja guru menjadi perlu agar mutu proses pembelajaran dapat berkesinambungan.

Guru yang berkompeten dalam mengajar dan memiliki komitmen turut menentukan baik tidaknya proses pembelajaran. Hal ini dapat dibuktikan melalui penelitian Rosdiana (2013) yang menyebutkan bahwa variabel kompetensi guru dan komitmen mengajar secara bersamasama (Silmutan) berpengaruh terhadap efektivitas proses pembelajaran. Besarnya pengaruh kompetensi guru dan komitmen mengajar terhadap efektivitas proses pembelajaran adalah 0,0487 atau sebesar 4,87\%.

\section{Standar Kompetensi Lulusan}

Pada Grafik 3 menunjukkan bahwa peningkatan pencapaian standar kompetensi lulusan dari tahun 2011 sampai 2013 cukup besar. Pada tahun 2011 ke tahun 2012 peningkatannya sebesar 6,46, sedangkan peningkatan dari tahun 2012 ke tahun 2013 sebesar 3,26. Hal

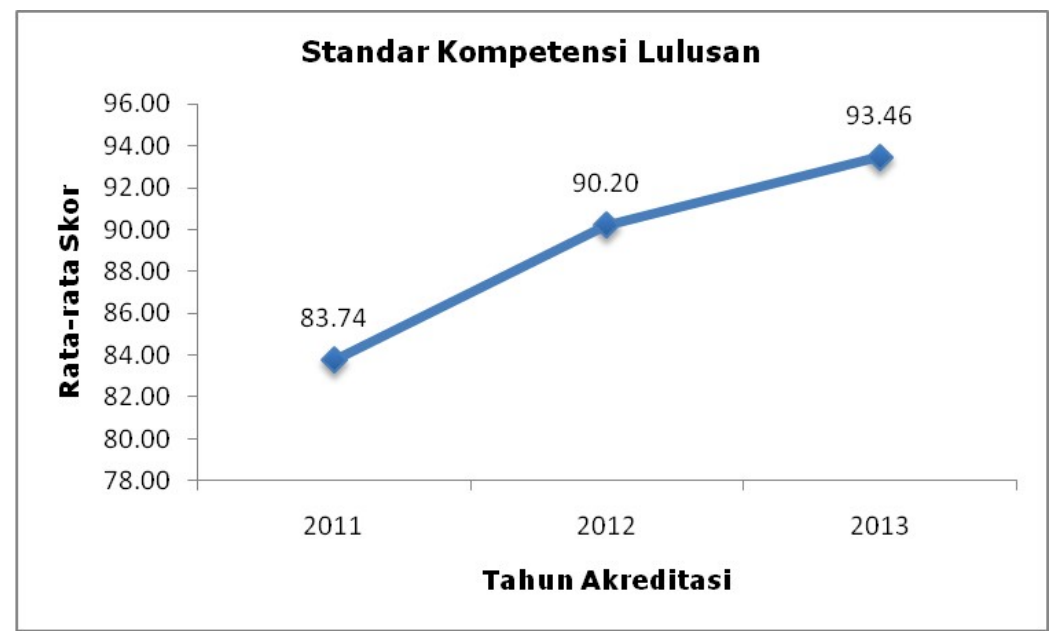

Grafik 3 Kecenderungan Rata-rata Skor Nilai Standar Kompetensi Lulusan Hasil Akreditasi 
yang perlu ditingkatkan dalam standar kompetensi lulusan adalah aspek pengalaman belajar yang memanfaatkan lingkungan secara produktif. Terdapat $5,21 \%$ sekolah yang siswanya memiliki pengalaman belajar dengan memanfaatkan lingkungan secara produktif hanya 1 jenis bahkan belum sama sekali dalam tiga tahun terakhir. Sebanyak 4,2\% sekolah memberikan tugas terstruktur untuk mata pelajaran Iptek kurang dari $61 \%$. Selanjutnya, $2,37 \%$ sekolah tidak pernah menjalankan kegiatan pembelajaran yang mampu memanfaatkan lingkungan secara produktif dan bertanggung jawab.

Sekolah di DKI Jakarta sebagian besar memiliki lahan yang kurang memadai untuk aktivitas siswa dengan memanfaatkan lingkungan secara produktif, namun hal ini dapat diantisipasi dengan mengajak siswa menggunakan media lain seperti pot untuk media tanaman. Sebagian sekolah sudah memanfaatkan sampah atau limbah untuk diolah menjadi pupuk, namun di 2,37\% sekolah belum melakukannya. Kepala sekolah dan pengawas dapat membagi pengalaman yang dimiliki dalam pemanfaatan lingkungan secara produktif ke sekolah lain melalui forum kepala sekolah atau melalui pengawasan rutin yang dilakukan oleh pengawas.

Sebesar 3,79 sekolah tidak memiliki kumpulan karya tulis siswa dan 3,79 sekolah tidak memfasilitasi kegiatan siswa untuk berkomunikasi baik lisan maupun tulisan secara efektif dan santun. Walaupun persentase sekolah yang kurang termasuk kecil namun hal ini perlu menjadi perhatian. Kebiasaan menulis dapat ditumbuhkan dengan membiasakan membaca buku. Menulis dapat tumbuh karena pengetahuan bertambah. Biasanya sekolah memberi kesempatan kepada siswa untuk membuat karya tulis menjelang siswa lulus sebagai salah satu persyaratan yang harus dipenuhi, selain melatih siswa berpikir kritis, menuangkan gagasan dan sekolah dapat menambah kumpulan karya tulis siwa.

Peran kepala sekolah, guru, tenaga kependidikan dan siswa dalam berkomunikasi secara santun perlu dibudayakan di semua sekolah. Biasakan siswa berkomunikasi menggunakan bahasa Indonesia yang baik dan benar dalam forum resmi di sekolah. Berbahasa Indonesia yang baik dan benar membuat anak menjadi lebih santun dalam berbicara karena bahasa Indonesia yang benar memiliki gramatikal yang teratur dan sistematis.

Kompetensi lulusan yang memiliki kemampuan akademik baik, terampil dan sigap dalam bekerja, jujur dan benar dalam bertindak, sopan santun dalam berkata dan berperilaku menjadi dambaan semua sekolah untuk meluluskannya. Menjadi penting mengintegrasikan semua kompetensi tersebut dalam satu kesatuan

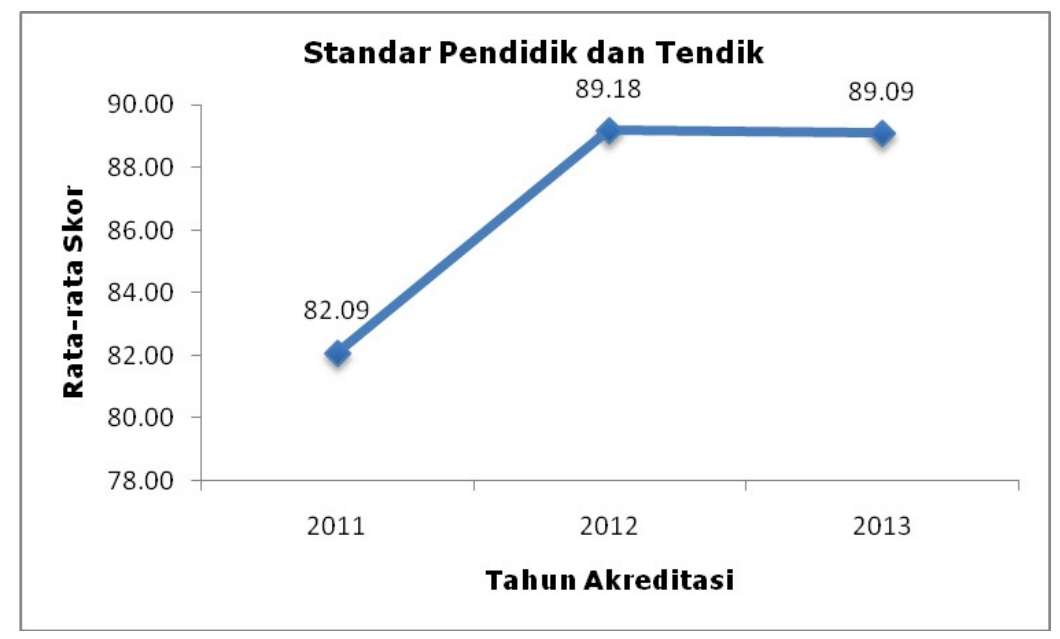

Grafik 4 Kecenderungan Rata-rata Skor Nilai Standar Kompetensi Lulusan Hasil Akreditasi 
kegiatan sekolah untuk dibiasakan dan menjadi budaya.

\section{Standar Pendidik dan Tenaga Kependidikan}

Nilai akreditasi standar pendidik dan tenaga kependidikan terus mengalami peningkatan dari tahun 2011 sampai tahun 2012 sebesar 7,09 dan sedikit mengalami penurunan pada tahun 2013 sebesar 0,09. Namun, pencapaian standar pendidik dan tenaga kependidikan dilihat dari hasil akreditasi tergolong paling rendah sebesar 82,09 pada tahun 2011 sebesar 89,18 pada tahun 2012 sebesar 89,09 pada tahun 2013 dibandingkan dengan standar lainnya.

Tenaga pendidik sebesar $95,73 \%$ telah memiliki kualifikasi pendidikan DIV/S1. Hal yang perlu diperhatikan adalah tenaga kependidikan. sebesar $13,27 \%$ sekolah tidak memiliki tenaga perpustakaan, kalaupun memiliki tenaga perpustakaan 12,32\% kualifikasinya di bawah SMA dan tidak memiliki sertifikat. Sebesar $14,69 \%$ sekolah tidak memiliki kepala perpustakaan dan $16,59 \%$ sekolah memiliki kepala perpustakaan dengan kualifikasi D2 bukan ilmu perpustakaan dan tidak memiliki sertifikat kompetensi pengelolaan perpustakaan. Sebesar $5,21 \%$ sekolah tidak memiliki tenaga administrasi dengan latar belakang pendidikan yang sesuai dengan bidangnya. Permasalahannya adalah tenaga kependidikan seperti tenaga perpustakaan dan tenaga administrasi tidak direkrut secara berkala oleh pemerintah sehingga banyak yang belum terpenuhi di SMA. Jika ada, tenaga kependidikan tersebut merupakan tenaga honorer yang diusahakan oleh sekolah. Hal ini menjadi masalah bila sekolah tidak boleh memungut dan tenaga kependidikan pun tidak disediakan.

DKI Jakarta memiliki jumlah distribusi guru SMA sebesar 13.141 orang (Direktorat Pembinaan Pendidik dan Tenaga Kependidikan Pendidikan Menengah, 2014). Artinya 95,73\% dari 13.141 guru SMA di DKI Jakarta telah memiliki kualifikasi pendidikan DIV/S1. Secara nasional jumlah guru SMA yang telah memiliki kualifikasi pendidikan S1 sebanyak 342.277 orang atau $94,37 \%$ (Pusat Data Statistik Pendidikan, 2015). Berdasarkan hasil akreditasi terdapat $93,84 \%$ guru SMA di DKI Jakarta yang memiliki sertifikat pendidik sesuai dengan mata pelajaran yang diampu, selain itu guru-guru tersebut juga menghasilkan karya tulis dan mengikuti berbagai pertemuan ilmiah. Terdapat fenomena secara nasional menumpuknya guru pada golongan IV/ a hingga masa pensiun.

Dibandingkan dengan jumlah guru negeri dan swasta seluruh Indonesia yang memiliki Ijazah S1 sebanyak 1.710 .299 orang $(62,32 \%)$, jumlah guru yang sudah disertifikasi secara nasional sebanyak 1.168 .405 orang $(45,27 \%)$, sedangkan guru yang belum bersertifikasi sebanyak 1.575 .974 (57,43\%) (Indardjo, 2014).

Kualifikasi guru SMA yang sudah D-IV/S1 sudah memadai di DKI Jakarta, namun berdasarkan data olahan dari Direktorat Jenderal Pendidik dan Tenaga Kependidikan nilai UKG secara nasional keseluruhan guru di DKI Jakarta, nilai rata-ratanya adalah 62,58 yang masih berada di atas rata-rata nasional 56,69. DKI Jakarta termasuk 7 provinsi yang memiliki nilai UKG di atas rata-rata nasional. Khusus guru SMA DKI Jakarta rata-rata nilai UKGnya 70,00, dengan nilai rata-rata nasional untuk guru SMA adalah 61,74 .

\section{Standar Sarana Prasarana}

Terdapat peningkatan nilai akreditasi dari tahun 2011 ke tahun 2012 sebesar 8,74 dan dari tahun 2012 ke tahun 2013 sebesar 0,06. Hal ini seiring dengan meningkatnya sarana dan prasarana di sekolah. Namun, masih terdapat sekolah yang kekurangan sarana dan prasarana dalam proses belajar mengajar. Sebanyak 10,90\% sekolah tidak memiliki ruang kelas dan gedung sendiri, artinya kepemilikan gedung bukan milik sendiri tetapi menyewa. Terdapat 4,27\% sekolah memiliki ruang kelas namun jumlah dan sarana tidak sesuai dengan ketentuan yang berlaku dalam standar sarana dan prasarana. Selain itu sebanyak $22,27 \%$ sekolah yang diakreditasi tidak memiliki ruang perpustakaan dan sebanyak 


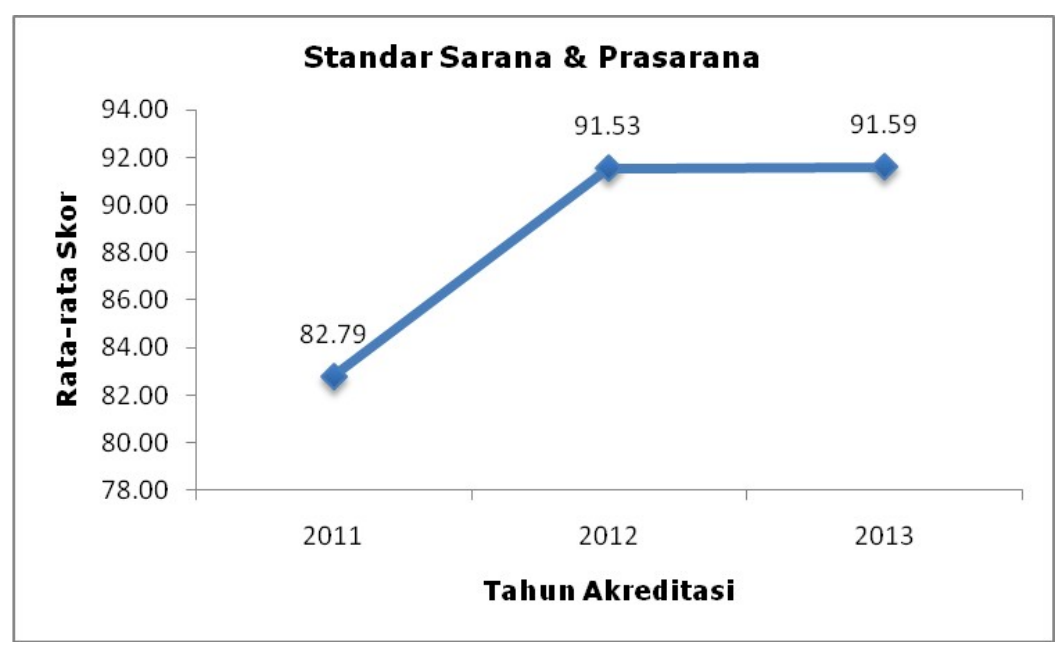

Grafik 5 Trend Rata-rata Skor Nilai Standar Sarana \& Prasarana Hasil Akreditasi

$4,74 \%$ sekolah memiliki ruang perpustakaan namun luas dan sarana buku tidak sesuai dengan ketentuan dalam standar sarana. Sebanyak $25,12 \%$ sekolah tidak memiliki ruang laboratorium Biologi. Sebanyak 34,12\% tidak memiliki ruang laboratorium Kimia. Hanya sebagian kecil sekolah yakni $5,7 \%$ yang tidak memiliki tempat ibadah. Sekolah yang nyaman, aman, tidak bising, dan terhindar dari pencemaran merupakan persyaratan yang seharusnya dipenuhi untuk menyelenggarakan pendidikan. DKI Jakarta yang sekolahnya terletak di kota tidak dapat terhindar dari pencemaran udara. Terdapat 1,42\% sekolah di Jakarta yang tidak berada pada lokasi yang nyaman dan terdapat $1,90 \%$ sekolah yang berada di lokasi nyaman, terhindar dari gangguan, pencemaran air dan kebisingan tapi tidak terhindar dari gangguan pencemaran udara serta tidak memilik sarana untuk meningkatkan kenyamanan.

Berdasarkan penelitian Handayani, dkk (2014b) ditemukan bahwa ketersediaan ruang perpustakaan di Indonesia dengan sampel 160 sekolah adalah $87 \%$ di sekolah swasta dan $82,5 \%$ di sekolah negeri, namun tingkat ketercukupan bukunya belum memadai. Artinya ketersediaan ruang perpustakaan sudah cukup baik, hanya buku-buku yang ada di dalamnya belum lengkap dan belum mencukupi sesuai dengan jumlah siswa.

Hal ini sejalan dengan hasil penelitian Muarief (2014) yang menunjukkan bahwa ketersediaan perpustakaan di Indonesia 87,685 dari 12.107 sekolah. Ketersediaan 5 jenis laboratorium Biologi, laboratorium Fisika, laboratorium Kimia, laboratorium komputer dan laboratorium bahasa dari 12.107 sekolah $\times 5$ macam laboratorium = 60.535 laboratorium, yang tersedia $43,37 \%$. Gambaran secara umum dari seluruh Indonesia menunjukkan masih banyak kekurangan 5 macam laboratorium. DKI Jakarta sebagai pusat pemerintahan tentunya juga secara umum ketersediaan laboratoriumnya cukup memadai, hanya perlu menambahkan kekurangan ketersediaan ruangan dan meng-ganti alat-alat yang sudah lama dengan alat-alat baru. Oleh karena Jakarta menjadi ukuran kemajuan pendidikan di Indonesia, maka alat dan bahan praktik yang disediakan untuk pembelajaran mestinya merupakan keluaran terbaru, sehingga siswa dapat mengikuti perkembangan zaman.

\section{Standar Pengelolaan}

Seperti standar lainnya, nilai standar pengelolaan meningkat tajam dari tahun 2011 ke tahun 2012 dan terus meningkat hingga tahun 2013. Standar pengelolaan meliputi perencanaan, pelaksanaan dan evaluasi. Pada tahap perencanaan, sekolah memiliki visi dan misi sekolah serta rencana kerja sekolah, selanjutnya pada tahap pelaksanaan, sekolah melibatkan masyarakat dan membina kemitraan dengan lembaga lain. Pada kenyataannya $3,79 \%$ sekolah tidak memiliki program pengelolaan pembiayaan pendidikan. 


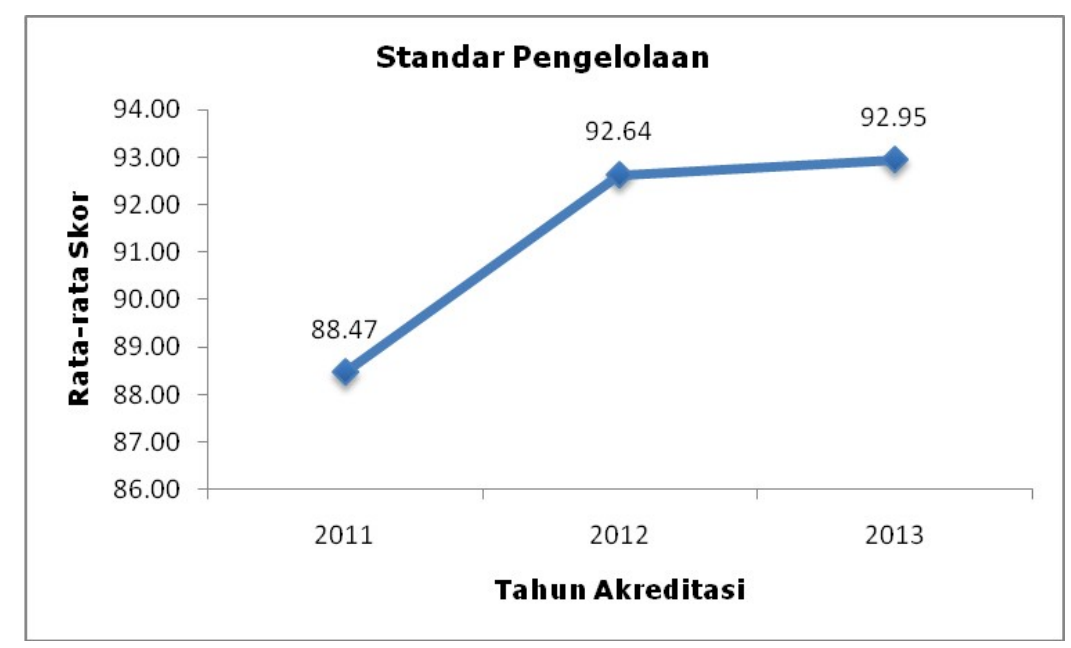

Grafik 6 Trend Rata-rata Skor Nilai Standar Pengelolaan Hasil Akreditasi

Sebesar 2,84\% sekolah tidak memiliki misi. $2,37 \%$ sekolah tidak memiliki kegiatan yang melibatkan masyarakat dan membangun kemitraan dengan lembaga lain yang relevan dalam pengelolaan pendidikan satu tahun terakhir.

Program pengelolaan pembiayaan pendidikan terdiri dari beberapa jenis yakni sumber pemasukan, pengeluaran dan jumlah dana yang dikelola, kewenangan dan tanggung jawab kepala sekolah/madrasah dalam membelanjakan anggaran pendidikan, pembukuan semua penerimaan dan pengeluaran dan penggunaan anggaran untuk dilaporkan komite sekolah/ madrasah dan institusi di atasnya. Artinya dana yang masuk ke sekolah seharusnya dikelola dan dipergunakan sesuai dengan peruntukannya dengan pembukuan yang rapi dan dapat dipertanggungjawabkan.

Visi dan misi merupakan dua hal yang tidak dapat dipisahkan. Visi merefleksikan apa yang ingin dicapai oleh organisasi, tanpa visi, sebuah organisasi tidak akan mampu merancang suatu rencana dan bagaimana untuk mencapainya. Sementara itu misi menggambarkan apa harus dilakukan organisasi untuk mencapai visinya. Karena biasanya visi bersifat ideal, misi mengklarifikasi dan menentukan berbagai aspek praktis terkait apa yang akan dilakukan oleh organisasi (Tjahjono, 2011). Untuk itu, visi dan misi penting ada dalam isntitusi termasuk satuan pendidikan. Sekolah biasanya menyesuaikan visi dan misinya dengan visi dan misi pemerintah daerah. Visi dan misi sekolah mencerminkan apa yang akan dicapai oleh sekolah. Peserta didik dan orang tua dapat melihat apa yang diinginkan oleh sekolah melalui visi dan misinya.

Pada masa sekarang nilai-nilai dalam organisasi menjadi hal yang penting. Menurut Tjahjono (2011), nilai-nilai organisasi menjadi sangat penting dalam kaitannya dengan kepentingan antara lain masyarakat dan lingkungan. Nilai organisasi wajib memenuhi harapan-harapan sosial, dalam hubungannya dengan kelangsungan hidup lingkungan sekitar serta tanggung jawab sosial. Hal ini juga berlaku di satuan pendidikan. Sekolah perlu melibatkan masyarakat dan membina kemitraan dengan lembaga lain guna menjalin hubungan dengan masyarakat dan memiliki jaringan kerja sama dengan lembaga lain.

Peran kepala sekolah tidak kalah pentingnya terhadap pengelolaan sekolah. Penelitian Diana (2009) menyatakan bahwa kepemimpinan kepala sekolah sangat berpengaruh langsung terhadap lingkungan kerja sebesar 35,5\%. Kepemimpinan kepala sekolah juga berpengaruh langsung terhadap motivasi kerja guru sebesar $17,5 \%$. Jadi dalam mengelola sekolah kepala sekolah memerlukan lingkungan kerja yang kondusif didukung oleh guru-guru yang termotivasi untuk mewujudkan tujuan sekolah yang sudah direncanakan secara bersama-sama. 


\section{Standar Pembiayaan}

Nilai akreditasi standar pembiayaan meningkat. Sebesar 5,14\% dari tahun 2011 ke tahun 2012 dan sebesar 0,19 dari tahun 2012 ke tahun 2015. Namun, terdapat beberapa hal yang harus diperhatikan untuk diperbaiki. Sebanyak 11,85\% sekolah yang mengelola sumbangan pendidikan atau dana dari masyarakat tidak efisien, tidak akuntabel dan tidak dilaporkan kepada komite sekolah atau yayasan. Sebanyak 17,06\% sekolah dan kurang dari $61 \%$ siswa dari keluarga tidak mampu mendapatkan keringanan uang sekolah. Sebanyak $14,22 \%$ sekolah yang siswanya dikenakan biaya daftar ulang setiap awal tahun. Sebanyak 9,95\% sekolah melakukan 3 jenis biaya pungutan biaya personal lain di luar uang sekolah. Sekolah yang diakreditasi pada tahun 2011, 2012 dan 2013 meliputi sekolah negeri dan sekolah swasta. Sekolah swasta di DKI Jakarta masih mengelola sumbangan pendidikan atau dana dari masyarakat. Sekolah negeri sejak tahun 2013 diberlakukan gratis di DKI Jakarta, sejak saat itu tidak ada pungutan apapun untuk siswa. Kebijakan tersebut tentunya membawa perubahan besar bagi sekolah negeri, sehingga siswa kurang mampu juga tidak perlu membayar di sekolah negeri bahkan siswa tersebut mendapat kartu Jakarta Pintar yang dapat menunjang kebutuhan personalnya seperti baju seragam, tranportasi dan kebutuhan gizinya, tentunya dengan beberapa persyaratan.
Oleh karena itu, sekolah seharusnya mampu mengelola keuangan yang ada sehingga dapat menghindari penggunaan biaya yang tidak perlu/ tidak direncanakan dalam Rencana Anggaran Pendapatan dan Belanja Sekolah (RAPBS). Menurut Ferdi (2013), efektivitas pembiayaan merupakan salah satu alat ukur efisiensi, sehingga program kegiatan tidak hanya dihitung berdasarkan biaya tetapi juga waktu, dan lebih amat penting lagi menghindari dan menseleksi penggunaan dana operasional, pemeliharaan dan biaya lain yang mengarah pada pemborosan.

Meningkatnya nilai standar pembiayaan dari tahun ke tahun juga salah satunya adanya program BOS, sehingga pertanggungjawaban dari sekolah semakin diawasi, sehingga sekolah lebih disipiin dalam membuat laporan keuangan. Masalahnya adalah kebutuhan pengeluaran SMA negeri per siswa per tahun dalam Purwadi (2015) adalah Rp2.927.713 dan SMA swasta rata-rata Rp3.232.283 per siswa per tahun. Mengingat besarnya BOS adalah sama untuk seluruh sekolah menengah yakni Rp1.000.000 per siswa per tahun pada tahun 2014, maka proporsi BOS dalam membantu biaya operasional sekolah juga beragam. Sekolah swasta di DKI Jakarta masih memungut pembayaran dari orangtua siswa. Sekolah swasta terutama yang favorit harus menambah lebih banyak biaya untuk menutupi kekurangan dana BOS yang diberikan Pemerintah. Hasilnya sekolah swasta dalam penilaian akreditasi masih banyak memungut biaya dari

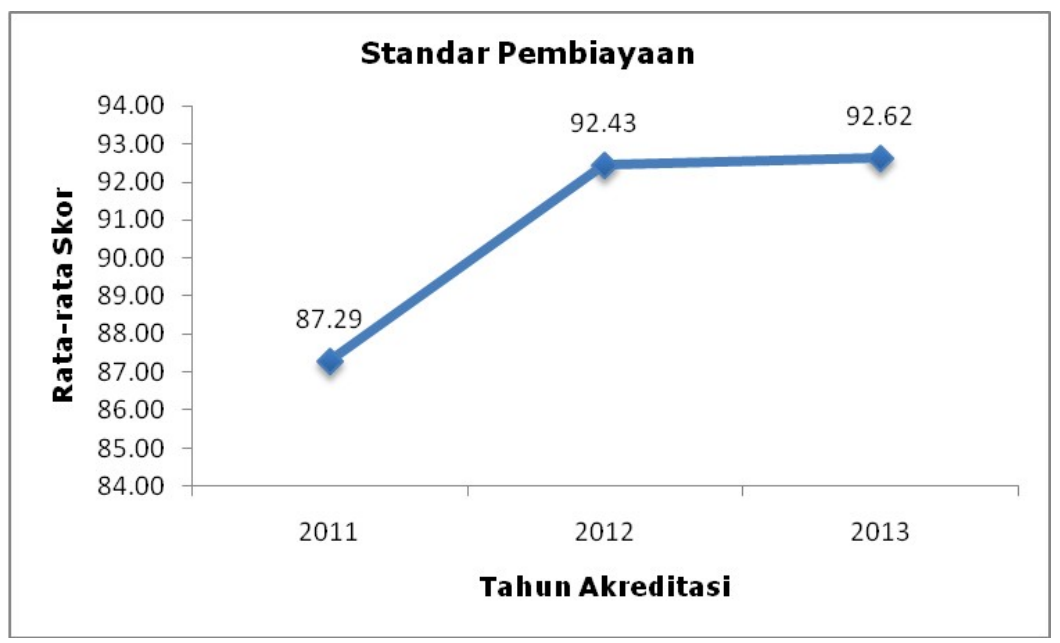

Grafik 7 Kecenderungan Rata-rata Skor Nilai Standar Pembiayaan Hasil Akreditasi 
orangtua sehingga penilaian akreditasi menjadi kurang. Penilaian akreitasi selain melihat besar biaya yang dipungut, juga melihat prestasi yang diperoleh oleh sekolah tersebut apakah seimbang.

\section{Standar Penilaian}

Standar penilaian meliputi penilaian oleh guru, sekolah dan oleh pemerintah. Penilaian oleh Pemerintah berupa Ujian Nasional pada tahun 2011, 2012 dan 2013 masih menentukan kelulusan bagi siswa. Berdasarkan analisis hasil jawaban penilaian akreditasi sebanyak 30,81\% sekolah menentukan kelulusan sama dengan kriteria yang berlaku. Sebanyak 4,27\% sekolah tidak menggunakan UN SMP/MTs/Paket B sebagai penentu penerimaan siswa baru. Agar sekolah tidak mengadakan tes seleksi lagi maka sekolah selayaknya menggunakan hasil UN SMP/ MTs untuk penerimaan siswa baru pada jenjang yang lebih tinggi. SMA negeri di DKI Jakarta sudah menggunakan sistem online dalam melaksanakan penerimaan peserta didik baru berdasarkan nilai Ujian Nasional SMP/MTs/Paket B. Bagi SMA swasta, penerimaan siswa baru biasanya dilakukan dengan tes masuk yang diselenggarakan oleh sekolah masing-masing, ada juga sekolah swasta yang menggunakan hasil UN SMP untuk syarat penerimaan siswa.

Penentuan kelulusan berbeda-beda setiap tahunnya. Pada tahun sebelum 2015, Ujian Nasional masih menjadi penentu kelulusan dengan porsi hitungan 40\% Nilai Sekolah dan 60\% nilai Ujian Nasional. Mulai tahun 2015 Ujian Nasional tidak lagi menjadi penentu kelulusan. Kelulusan pada tahun 2015 ditentukan oleh sekolah. Perbaikan yang perlu dilakukan berdasarkan hasil akreditasi adalah sekolah sebagai lembaga pendidikan memiliki peluang menggunakan haknya dalam menentukan kelulusan siswa dengan sistem penilaian yang valid dan objektif. Seperti apapun bentuk penilaiannya yang menjadi muara akhir adalah tercetaknya lulusan yang kompeten. Walaupun Ujian Nasional tidak menjadi penentu kelulusan, namun sebagian besar sekolah menggunakannya untuk penerimaan siswa baru pada jenjang yang lebih tinggi, hanya beberapa sekolah saja yang melakukan tes masuk tanpa menggunakan hasil UN untuk seleksi penerimaan siswa baru.

Selain penilaian terhadap pengetahuan melalui Ujian Nasional, kemampuan keterampilan siswa juga dilihat melalui ujian praktik, sikap siswa juga menjadi penentu lulus tidaknya siswa. Nilai ujian sekolah juga menjadi salah satu yang dinilai dalam menentukan kelulusan. Seperti yang ditulis Safari (2015), UN, termasuk Ujian Sekolah, merupakan satu kesatuan proses belajar mengajar di sekolah. UN bukan suatu kegiatan terpisah dalam pembelajaran. Dalam UN materi yang diujikan hanya mengukur aspek kognitif, tes tertulis, dan bentuk soalnya hanya pilihan ganda, dengan kondisi seperti ini, guru di sekolah dalam menyusun soal untuk keperluan

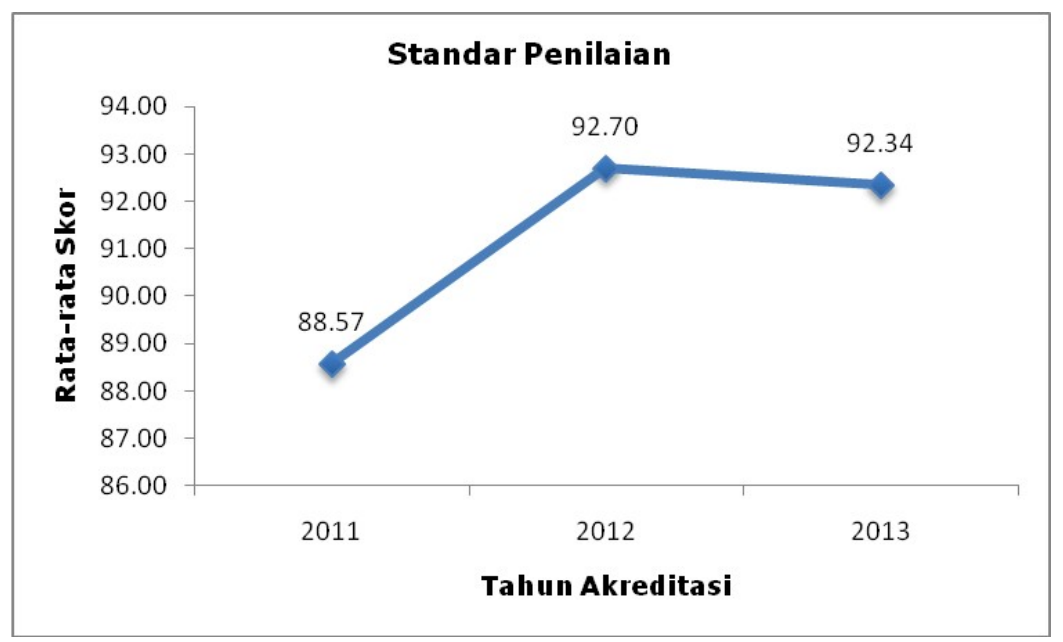

Grafik 8 Kecenderungan Rata-rata skor nilai Standar Penilaian Hasil Akreditasi 
ujian sekolah (US) seharusnya tidak hanya menyakan aspek kognitif lagi karena sudah diujikan di UN. Seharusnya pada US menanyakan aspek psikomotorik dan afektifnya. UN mempergunakan bentuk soal pilihan ganda dengan tujuan penskorannya objektif, akurat, dan hasilnya cepat dapat diumumkan secara nasional karena menggunakan scanner dan komputer. Adapun proses belajar mengajar di kelas di dalamnya termasuk penilaian proses (formatif) dan penilaian hasil (sumatif) dengan demikian antara penilaian proses dan hasil tidak bisa dipisahkan.

Tabel 1 merupakan gambaran secara keseluruhan kecenderungan pencapaian 8 SNP mulai dari tahun 2011 sampai dengan tahun 2013. Hasil pencapaian akreditasi di daerah DKI Jakarta tergolong baik, tidak terlepas dari berbagai kekurangan yang perlu diperbaiki. Hasil akreditasi menjadi salah satu penjaminan mutu sekolah dapat dimanfaatkan dengan baik termasuk bagian apa saja yang perlu diperbaiki melalui koordinasi dengan pemerintah daerah.

Hasil akreditasi yang sudah dianalisis berdasarkan jawaban pertanyaan perangkat akreditasi sangat berguna untuk memperbaiki mutu pendidikan sekolah. Menurut Hendarman
(2013), jika akreditasi sekolah sekadar memotret keadaan sekolah tanpa impikasi lanjutan untuk meningkatkan mutu pendidikan, maka sumber daya besar yang dikeluarkan untuk proses akreditasi tak sebanding dengan yang didapat.

Ketercapaian Standar Nasional Pendidikan dapat diukur melalui hasil akreditasi per komponen. Badan Akreditasi Provinsi juga memiliki nilai akreditasi hasil penilaian dari asesor. Jawaban sekolah atas pertanyaan dalam perangkat akreditasi dapat dianalisis untuk mengetahui jawaban yang kurang. Jawaban yang nilainya kurang berkisar pada jawaban pilihan D dan E. Analisis yang lebih detail berkaitan dengan jawaban sekolah tersebut dapat dijadikan bahan perbaikan sekolah terhadap komponen yang dianggap kurang dapat dicapai oleh sekolah.

Hasil akreditasi menurut Subijanto (2014) dapat memberikan manfaat bagi kepala sekolah sebagai bahan masukan untuk penyusunan program serta anggaran pendapatan dan belanja sekolah/madrasah. Bagi dinas pendidikan, sebagai bahan pertimbangan dalam menyusun program pembinaan teknis sesuai dengan kebutuhan masing-masing sekolah/ madrasah. Bagi pemerintah daerah, hasil

Tabel 1 Pencapaian 8 SNP

\begin{tabular}{llccc}
\hline No. Standar & 2011 & 2012 & 2013 \\
\hline 1. & Standar Isi & 87,84 & 92,08 & 92,73 \\
2. & Perkembangan & & 4,24 & 0,65 \\
2. & Standar Proses & 85,36 & 89,6 & 90,25 \\
& Perkembangan & & 4,24 & 0,65 \\
3. & Standar Kompetensi Lulusan & 83,74 & 90,2 & 93,46 \\
& Perkembangan & 6,46 & 3,26 \\
4. & Standar Pendidik dan Tenaga Kependidikan & 82,09 & 89,18 & 89,09 \\
& Perkembangan & & 7,09 & $-0,09$ \\
5. & Standar Sarana Prasarana & 82,79 & 91,53 & 91,59 \\
& Perkembangan & 8,74 & 0,06 \\
6. & Standar Pengelolaan & 88,74 & 92,64 & 92,95 \\
& Perkembangan & & 3,9 & 0,31 \\
7. & Standar Pembiayaan & 87,29 & 92,43 & 92,62 \\
& Perkembangan & & 5,14 & 0,19 \\
8 & Standar Penilaian & 88,70 & 92,70 & 92,34 \\
& Perkembangan & & 4 & $-0,36$ \\
\hline
\end{tabular}

Sumber: Hasil pengolahan data Akreditasi tahun 2011,2012 dan 2013. 
akreditasi digunakan sebagai acuan dalam memetakan mutu dan kelayakan sekolah/ madrasah untuk mempermudah usaha-usaha pembinaan dan pemberdayaan serta sumber informasi yang dapat digunakan sebagai dasar dalam menentukan kebiajkan pembangunan pendidikan di setiap daerah (BAN-S/M,2010).

Pihak sekolah dan pemerintah daerah dapat melakukan perbaikan mutu sekolah melalui koordinasi dengan Badan Akreditasi Provinsi dan Badan Akreditasi Nasional Sekolah Menengah untuk melakukan pemetaan berkaitan dengan pencapaian Standar Nasional Pendidikan. Setelah itu, baru dilakukan analisis yang lebih mendalam tentang hal apa saja yang perlu diperbaiki. Pengetahuan tentang hal apa saja yang perlu diperbaiki dapat diperoleh melalui jawaban sekolah terhadap butir pertanyaan perangkat akreditasi. Pemetaan sekolah berdasarkan hasil akreditasi dapat dilakukan oleh pihak dinas pendidikan untuk dasar perbaikan mutu pendidikan oleh pemerintah daerah.

Hal tersebut juga disebutkan oleh Subagya (2009) bahwa hasil akreditasi setidaknya dapat dijadikan acuan dalam upaya meningkatkan mutu sekolah/madrasah dan rencana pengembangan sekolah/madrasah. Terkait dengan memacu kinerja sekolah, hasil akreditasi dapat dijadikan umpan balik dalam usaha pemberdayaan dan pengembangan kinerja warga sekolah/madrasah dalam rangka menerapkan visi, misi, tujuan, sasaran, strategi dan program sekolah/madrasah. Di samping itu, hasil akreditasi sekolah/madrasah diharapkan mampu memotivasi sekolah/madrasah terus meningkatkan mutu pendidikan secara bertahap, terencana, dan kompetitif baik di tingkat kabupaten/kota, provinsi, nasional bahkan regional dan internasional.

Masyarakat terutama orang tua peserta didik sebagai pengguna pendidikan juga memiliki peran dalam meningkatkan mutu pelayanan pendidikan. Kritikan membangun dari orang tua dan motivasi bersifat semangat dan keuangan menjadi penting bagi sekolah untuk secara bersama mencapai pendidikan yang diinginkan.
Masyarakat juga berfungsi sebagai parameter apakah sebuah sekolah dikategorikan baik atau tidak karena masyarakat sebagai publik dapat menilai dan merasakan pelayanan yang diberikan sekolah terhadap anak-anaknya. Pilihan masyarakat untuk memilih salah satu sekolah untuk menitipkan anaknya belajar menjadi ukuran apakah sekolah tersebut baik atau tidak. Jika masyarakat menganggap sekolah tersebut layak untuk menjadi tempat mendidik anaknya, tentu karena pendidikannya dapat dipercaya dan dirasakan bermanfaat untuk masa depan anak.

Peringkat dan status akreditasi sudah menjadi acuan bagi orang tua peserta didik dalam memilih sekolah. Terlepas dari hasil akreditasi, kenyataan lulusan yang bermutu, sekolah yang nyaman, aman, kondusif untuk belajar menjadi alasan orang tua dalam memilih sekolah. Tingkat kepuasan orang tua dan peserta didik atas mutu pelayanan sekolah merupakan hal yang dapat dirasakan yang dapat memotivasi peserta didik untuk berprestasi.

\section{SIMPULAN DAN SARAN}

\section{Simpulan}

Terjadi peningkatan nilai akreditasi dari tahun 2011 ke tahun 2012 sampai tahun 2013. Kecenderungan peningkatan yang paling terlihat dari tahun 2011 ke tahun 2012 yaitu pencapaian standar pendidik dan tenaga kependidikan naik 7,09 , standar sarana prasarana menunjukkan kenaikan 8,74 dan standar kompentesi lulusan naik 6,49 . Kenaikan pada standar pembiayaan pada tahun 2011 ke tahun 2012 sebesar 5,14, standar isi 4,24, standar pengelolaan 3,9 dan standar penilaian 4. Di antara delapan standar yang paling rendah pencapaiannya baik pada tahun 2011, 2012 maupun 2013 yaitu standar pendidik dan tenaga kependidikan, terutama standar tenaga kependidikan masih kurang. Kekurangan yang perlu diperbaiki pada standar pendidik dan tenaga kependidikan adalah $13,27 \%$ sekolah tidak memiliki tenaga perpustakaan, kalaupun memiliki tenaga perpustakaan 12,32\% kualifikasinya di bawah 
SMA dan tidak memiliki sertifikat. $14,69 \%$ sekolah tidak memiliki kepala perpustakaan, dan $16,59 \%$ sekolah memiliki kepala perpustakaan dengan kualifikasi D2 bukan ilmu perpustakaan dan tidak memiliki sertifikat kompetensi pengelolaan perpustakaan. Sebesar 5,21\% sekolah tidak memiliki tenaga administrasi dengan latar belakang pendidikan yang sesuai dengan bidangnya.

Walaupun terjadi peningkatan pencapaian standar proses setiap tahunnya namun masih ada kekurangan yang ditemukan yakni, evaluasi proses pembelajaran yang dilakukan oleh $4,27 \%$ kepala sekolah hanya pada satu aspek, bahkan tidak melakukan evaluasi. Biasanya aspek yang paling diperhatikan adalah aspek pelaksanaan proses pembelajaran $(6,2 \%)$. Bagi sekolahsekolah yang menjalankan KTSP, sebesar $6,2 \%$ sekolah yang belum mengembangkannya secara mandiri. Terdapat 5,21\% sekolah yang siswanya memiliki pengalaman belajar dengan memanfaatkan lingkungan secara produktif hanya 1 jenis bahkan belum sama sekali dalam tiga tahun terakhir. 3,79 sekolah tidak memiliki kumpulan karya tulis siswa dan 3,79\% sekolah tidak memfasilitasi kegiatan siswa untuk berkomunikasi baik lisan maupun tulisan secara efektif dan santun.

Standar sarana prasarana walaupun pencapaiannya sudah meningkat setiap tahun, namun ada kekurangan yang harus dipenuhi. Sebesar 22,27\% sekolah yang diakreditasi tidak memiliki ruang perpustakaan dan sebanyak $4,74 \%$ sekolah memiliki ruang perpustakaan, namun luasnya dan sarana buku tidak sesuai dengan ketentuan dalam standar sarana. Sebesar 25,12\% sekolah tidak memiliki ruang laboratorium Biologi dan 34,12\% tidak memiliki ruang laboratorium Kimia.

Hal yang perlu ditingkatkan dalam standar kompetensi lulusan adalah aspek pengalaman belajar yang memanfaatkan lingkungan secara produktif. Terdapat $5,21 \%$ sekolah yang siswanya memiliki pengalaman belajar dengan memanfaatkan lingkungan secara produktif hanya satu jenis bahkan belum sama sekali dalam tiga tahun terakhir. Sebanyak 4,2\% sekolah memberikan tugas terstruktur untuk mata pelajaran Iptek kurang dari $61 \%$. Selanjutnya $2,37 \%$ sekolah tidak pernah menjalankan kegiatan pembelajaran yang mampu memanfaatkan lingkungan secara produktif dan bertanggung jawab.

Standar pengelolaan pencapaiannya pada tahun 2011 tertinggi di antara standar lainnya, namun peningkatannya pada tahun 2012 hanya $4,17 \%$. Kekurangan pada standar pengelolaan sebesar $2,37 \%$ sekolah tidak memiliki kegiatan yang melibatkan masyarakat dan membangun kemitraan dengan lembaga lain yang relevan dalam pengelolaan pendidikan satu tahun terakhir.

Aspek yang masih kurang dalam pencapaian standar isi adalah kesesuaian antara Standar Kompetensi, Kompetensi Dasar dan indikatorindikatornya di semua mata pelajaran $(3,32 \%)$ kurang sesuai. Selain itu, dari butir yang ditanyakan, yang kurang adalah keterlibatan berbagai pihak dalam penyusunan silabus mata pelajaran muatan lokal $(7,1 \%)$.

Terdapat beberapa hal yang harus diperhatikan untuk diperbaiki dalam pencapaian standar pembiayaan. Sebanyak $11,85 \%$ sekolah yang mengelola sumbangan pendidikan atau dana dari masyarakat tidak efisien, tidak akuntabel dan tidak dilaporkan kepada komite sekolah atau yayasan. Sebanyak $17,06 \%$ sekolah dan kurang dari $61 \%$ siswa dari keluarga tidak mampu mendapatkan keringanan uang sekolah. Sebanyak $14,22 \%$ sekolah yang siswanya dikenakan biaya daftar ulang setiap awal tahun. Sebanyak 9,95\% sekolah melakukan 3 jenis biaya pungutan biaya personal lain di luar uang sekolah. Sekolah swasta di DKI Jakarta masih mengelola sumbangan pendidikan atau dana dari masyarakat. Sekolah negeri sejak tahun 2013 diberlakukan gratis di DKI Jakarta, sejak saat itu tidak ada pungutan apa pun untuk siswa.

Berdasarkan analisis hasil jawaban penilaian akreditasi sebanyak 30,81\% sekolah menentukan kelulusan sama dengan kriteria yang 
berlaku. Sebanyak 4,27\% sekolah tidak menggunakan UN SMP/MTs/Paket B sebagai penentu penerimaan siswa baru.

Secara keseluruhan peningkatan akreditasi untuk ke delapan standar dari tahun 2011 ke tahun 2012 cukup besar, yakni paling sedikit meningkat 3,9\% untuk standar pengelolaan dan paling tinggi meningkat $8,74 \%$ untuk standar sarana prasarana. Terlihat bahwa peningkatan akreditasi dari tahun 2011 ke tahun 2012 menunjukkan bahwa pihak sekolah maupun pemerintah daerah berusaha meningkatkan kualitas delapan standar sehingga dapat mengalami kenaikan nilai pada tahun berikutnya. Nilai akreditasi pada tahun 2012 ke tahun 2013 juga mengalami peningkatan di bawah 3,26\%, kecuali standar kompetensi kelulusan mengalami peningkatan sebesar 3,26\%. Standar Pendidik dan Tenaga Kependidikan yang sedikit menurun pada tahun 2012, karena masih ada tenaga kependidikan seperti pustakawan dan administrasi yang belum sesuai dengan standar. Pencapaian ke delapan standar pendidikan di DKI Jakarta masih terdapat sedikit kekurangan yang perlu dipenuhi agar pencapaiannya maksimal.

\section{Saran}

Atas dasar simpulan beberapa saran dirumuskan sebagai berikut. Pertama, Pemerintah DKI Jakarta perlu memenuhi kekurangan tenaga kependidikan di sekolah-sekolah yang memerlukan terutama tenaga perpustakaan dan tenaga administrasi yang sesuai dengan bidang ilmunya. Kedua, kepala sekolah selayaknya mengadakan evaluasi standar proses, tidak hanya pada saat pelaksanaan proses pembelajaran tapi juga pada saat perencanaan pembelajaran dan evaluasi pembelajaran. Ketiga, dalam hal kompetensi lulusan walaupun sudah meningkat nilai akreditasinya dari tahun ke tahun namun masih ada kekurangan dalam jumlah yang sedikit. Hal yang perlu diperhatikan yaitu pemanfaatan lingkungan dalam belajar, baik di lingkungan sekolah maupun di luar sekolah. Kebiasaan menulis dapat ditumbuhkan melalui penyusunan karya tulis di kelas akhir. Pembudayaan berbahasa yang santun di sekolah dengan menggunakan bahasa Indonesia yang baik dan benar. Keempat, sarana prasarana yang perlu dipenuhi untuk meningkatkan pemenuhan standar sarana dan yaitu ruang perpustakaan, ruang laboratorium Biologi dan ruang laboratorium Kimia. Selain Prasarana berupa ruang, sarana yang ada seperti buku, alat dan bahan praktik yang diperlukan selayaknya dilengkapi sesuai dengan kebutuhan dan daya tampung ruangan. Bagi sekolah yang belum memiliki ruang laboratorium dan pemerintah daerah belum dapat memenuhi maka dapat disediakan alat dan bahan praktik berupa paket sesuai dengan kompetensi dasar yang dipraktikan. Alat dan bahan praktik untuk mata pelajaran Biologi, Fisika dan Kimia ini dapat dibawa-bawa dan aman dilakukan praktik di kelas. Kelima, pada bagian pembiayaan, pihak dinas pendidikan DKI perlu mengawasi pengelolaan keuangan di sekolah swasta agar dana masyarakat dapat dikelola dengan efisien dan akuntabel. Keenam, standar isi, pembuatan silabus muatan lokal perlu melibatkan komponen guru, kepala sekolah, pihak dinas pendidikan dan masyarakat yang kompeten. Ketujuh standar penilaian, nilai UN sebaiknya digunakan untuk salah satu syarat masuk ke jenjang yang lebih tinggi, terutama di sekolah swasta dan ke delapan pada standar pengelolaan, sekolah-sekolah yang dinilai belum melibatkan masyarakat dan membangun kemitraan dengan lembaga lain yang relevan perlu diberikan pengarahan dalam membentuk kemitraan. 


\section{PUSTAKA ACUAN}

Badan Standar Nasional Pendidikan. 2006. Panduan Penyusunan Kurikulum Tingkat Satuan Pendidikan Jenjang Pendidikan Dasar dan Menengah. Jakarta: BSNP.

Badan Akreditasi Nasional Sekolah/Madrasah. 2010. Kebijakan dan Pedoman Akreditasi Sekolah/ Madrasah, Balitbang, Kemdiknas, Jakarta.

Delors, J. 1996. Learning: Treasure Within, Report to UNESCO of The International Commision on The Twenty First Century. Paris: UNESCO.

Diana, N. 2009. Pengaruh Kepemimpinan, Lingkungan Kerja dan Motivasi Kerja Terhadap Kepuasan Kerja Guru. Jurnal Pendidikan dan Kebudayaan. 15(4) 684-705.

Direktorat Pembinaan Pendidik dan Tenaga Kependidikan Menengah. 2014. Perencanaan Kebutuhan Guru Sekolah Menengah Atas (SMA) Tahun 2014-2020 Berdasarkan Kurikulum 2013.

Dominggus, E. \& Papilaya, J. 2014. Analisis Mutu Proses Pembelajaran Pada Jenjang Sekolah Dasar dan Menengah di Kabupaten Seram Bagian Barat. Jurnal Penelitian Kebijakan Pendidikan. 7(3) 325-338

Ferdi W.P. 2013. Pembiayaan Pendidikan: Suatu Kajian Teoritis. Jurnal Pendidikan dan Kebudayaan. 19(4) 565-578.

Fatah, N. 2008. Pembiayaan Pendidikan: Landasan Teori dan Studi Empiris. Jurnal Pendidikan Dasar, http://file.upi.edu/Direktori/JURNAL/PENDIDIKAN_DASAR/Nomor_9-April_2008/ Pembiayaan_Pendidikan_Landasan_Teori_dan_Studi_Empiris.pdf (1-4) diakses 15 Agustus 2016.

Ghiselli, E. 1970. Explorations in Management Talent. California: Goodyear Publishing.

Hendarman. 2013. Pemanfaatan Hasil Akreditasi dan Kredibilitas Asesor Sekolah/Madrasah. Jurnal Pendidikan dan Kebudayaan. 19(4) 532-542.

Hendarman. 2014. Kendala-Kendala Pelaksanaan Evaluasi Diri Sekolah (EDS). Jurnal Pendidikan dan Kebudayaan. 20(1) 74-85.

Handayani, M. 2014. Tingkat Kepuasan siswa Terhadap Mutu Pelayanan Pendidikan di Sekolah Menengah Atas. Jurnal Data dan Statistik Pendidikan. 2(2) 70-88.

Handayani, M., Idris HM Noor, Rumtini, Rahmah A, Arie BS. 2014. Laporan Hasil Penelitian Pencapaian Peningkatan Mutu Pendidikan Menengah. Pusat Penelitian Kebijakan, Badan Penelitian dan Pengembangan, Kemdikbud.

Haryati, S. 2012. Pengembangan dan Peningkatan Mutu Pendidikan Sekolah dan Madrasah Melalui Proses Akreditasi. Ragam Jurnal Pengembangan Humaniora, 12(3) 199-204.

Harahap, S. S. 2009. Pengaruh Penerapan Standar Nasional Pendidikan Terhadap Kesempatan Kerja Lulusan Siswa SMK Negeri Kota Medan. Tesis (tidak dipublikasikan) Program Studi Perencanaan Pembangunan Wilayah dan Pedesaan (PWD) pada Sekolah Pascasarjana. Universitas Sumatera Utara. (73-201).

Indardjo.2014. Telaah Profil Profesionalitas Guru Indonesia. Jurnal Data dan Statistik Pendidikan. 2(1) $70-80$.

Kementerian Pendidikan Nasional, 2011, Analisis Akreditasi Sekolah/Madrasah, Dalam Rangka Reformasi Birokrasi Internal. Jakarta: Kementerian Pendidikan Nasional. 
Madus, G. E., \& Kellaghan, T. 2012. Curriculum evaluation and assessment in Jackson, P. M. (Edit, 1992). Handbook of research on curriculum. New York: McMillan Publishing Company.

Muarief, S. 2014. Profil Prasarana Pendidikan Menengah di Indonesia. Jurnal Data dan Statistik Pendidikan. 2(2) 143-153.

Panjaitan, O. M. 2013. Analisis Standar Isi Bahasa Inggris SMP dan SMA. Jurnal Pendidikan dan Kebudayaan. 19(1) 44-58.

Purwadi, A. 2015. Efektivitas Bantuan Operasional Sekolah (BOS) Pendidikan Menengah. Jurnal Penelitian Kebijakan Pendidikan. 8(2) 183-203.

Pusat Data dan Statistik Pendidikan dan Kebudayaan. 2015. Statistik Persekolah Tahun 2014/ 2015. Pusat Data dan Statisstik Pendidikan dan Kebudayaan, Kementerian Pendidikan dan Kebudayaan.

Peraturan Pemerintah Nomor 19 Tahun 2005 tentang Standar Nasional Pendidikan

Peraturan Menteri Pendidikan Nasional Republik Indonesia Nomor 69 Tahun 2009 tentang Standar Biaya Operasional Non Personalia

Peraturan Menteri Pendidikan Nasional Nomor 19 Tahun 2007 tentang Standar Pengelolaan Pendidikan

Peraturan Menteri Pendidikan Nasional Nomor 24 Tahun 2007 tentang Standar Sarana dan Prasarana

Peraturan Menteri Pendidikan dan kebudayaan Nomor 59 tahun 2012 tentang Badan Akreditasi Nasional

Peraturan Menteri Pendidikan Nasional Nomor 54 tahun 2013 tentang Standar Kompetensi Lulusan (SKL) Pendidikan Dasar dan Menengah.

Rosdiana, D. 2013. Pengaruh Kompetensi Guru Dan Komitmen Mengajar Terhadap Efektivitas Proses Pembelajaran Serta Implikasinya Pada Hasil Belajar Siswa Dalam Mata Pelajaran Ekonomi. Jurnal Penelitian Pendidikan. 13(2) 202-209.

Safari. 2015. Ujian Nasional Sebagai Cermin Mutu Pendidikan dan Pemersatu Bangsa. Jurnal Pendidikan dan Kebudayaan, 21(2) 101-113.

Sanjaya, W. 2006. Strategi Pembelajaran: Berorientasi Standar Proses Pendidikan. Jakarta: Kencana.

Subagya. 30 November 2009. Implikasi Akreditasi Sekolah. Kedaulatan Rakyat. hlm 5.

Subijanto. 2014. Penggunaan Data dan Informasi Hasil Kinerja Badan Akreditasi Nasional Sekolah/Madrasah. Jurnal Data dan Statistik Pendidikan. 2(1) 134-150.

Tjahyono, H. 2011. Culture Based Leadership. Jakarta: PT Gramedia.

Tilaar, H. A. R. 2006. Standarisasi Pendidikan Nasional: Suatu Tinjauan Kritis. Jakarta: PT Rineka Cipta.

Undang-Undang Dasar Negara Kesatuan Republik Indonesia Tahun 1945 (amandemen)

Undang-Undang Nomor 20 Tahun 2003 tentang Sistem Pendidikan Nasional. 
